\title{
Legal Origins, Civil Procedure, and the Quality of Contract Enforcement
}

\section{Citation}

Holger Spamann, Legal Origins, Civil Procedure, and the Quality of Contract Enforcement, $166 \mathrm{~J}$. Institutional \& Theoretical Econ. 149 (2010).

\section{Published Version}

http://dx.doi.org/10.1628/093245610790711591

\section{Permanent link}

http://nrs.harvard.edu/urn-3:HUL.InstRepos:12025612

\section{Terms of Use}

This article was downloaded from Harvard University's DASH repository, and is made available under the terms and conditions applicable to Open Access Policy Articles, as set forth at http:// nrs.harvard.edu/urn-3:HUL.InstRepos:dash.current.terms-of-use\#OAP

\section{Share Your Story}

The Harvard community has made this article openly available.

Please share how this access benefits you. Submit a story.

Accessibility 


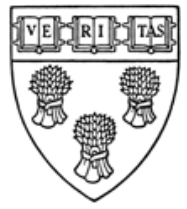

Harvard Law School

Public Law \& Legal Theory Working Paper Series

Paper No. 09-51

\title{
Legal Origin, Civil Procedure, and the Quality of Contract Enforcement
}

\author{
Holger Spamann \\ Harvard Law School
}

This paper can be downloaded without charge from the Social Science

Research Network (SSRN) electronic library. 


\title{
Legal Origin, Civil Procedure, and the Quality of Contract Enforcement
}

\author{
by \\ Holger SpamanN*
}

\begin{abstract}
This paper empirically compares civil procedure in common law and civil law countries. Using World-Bank and hand-collected data, and unlike earlier studies that used predecessor data sets, this paper finds no systematic differences between common and civil law countries in the complexity, formalism, duration, or cost of procedure in courts of first instance. The paper further finds that by a subjective measure, contract enforceability in common law countries is higher than in French, but lower than in German and Scandinavian, civil law countries. Given civil procedure's central role for the common/civil law distinction, these findings challenge the distinction's economic relevance. (JEL: K40, K41, P51)
\end{abstract}

*For helpful comments and encouragement, I thank Lucian Bebchuk, Brian Cheffins, Daniel Chen, Stavros Gadinis, Martin Gelter, Louis Kaplow, Katerina Linos, Ralf Michaels, Eduardo Morales, Mark Ramseyer, Ivan Reidel, Mark Roe, Steve Shavell, Stefan Voigt, and participants of the 2009 JITE conference at Kloster Eberbach, particularly Jonathan Klick and Gerhard Wagner. The English material in the Appendix was compiled by Sarah Ford, and judges Marie-Odile Devillers and I. Zeidler provided very helpful feedback on the French and German materials, respectively; I am extremely grateful to all of them. I gratefully acknowledge financial support provided by a Terence M. Considine Fellowship through the John M. Olin Center for Law, Economics, and Business at Harvard Law School. 


\section{Introduction}

The divergence of common and civil law began with reforms of judicial organization and procedure in England during the reign of Henry II (DAwsON [1968]; Caenegem [1988]). Today, even scholars who otherwise see few relevant differences between contemporary common and civil law agree that there are still important differences in the area of judicial adjudication and enforcement of private claims (civil procedure). In particular, common law jurisdictions tend to concentrate the trial, to involve the parties in the collection of evidence, and to curb appeals, more than civil law countries (GOLDSTEIN [1995]; Zweigert And Kötz [1998]). Do these structural differences lead to measurable differences in performance, and/or can they be captured by simple measures of complexity and formalism?

Two seminal empirical studies have answered these questions in the affirmative. The World Bank's first Doing Business report and one of its background studies constructed and collected measures of the complexity, formalism, duration, and cost of civil procedure in courts of first instance in 133 and 109 countries, respectively, in or around the year 2003. They found that civil law countries had on average more complex and formalist procedures, and that more complex and formalist procedures were in turn longer and costlier, with no offsetting benefits in terms of securing better justice (World BAnK [2004]; DJAnkov ET AL. [2003]).

This paper revisits these questions with improved and expanded data, and finds no systematic differences between common and civil law countries. Most of the paper's conclusions are based on corrections of the earlier data by the World Bank itself. Its latest Doing Business report presents corrected and expanded data on complexity, duration, and cost for now up to 181 countries in the years 2003-2008 (WORLD BANK [2009a]). As section 2 shows, these new data confirm that complexity may induce delay and expense without furthering justice in other ways, but they do not reveal any differences between common and civil law countries on any of these three measures. In other words, the original findings that civil procedure in civil law countries was more complex, protracted, and costly than in common law countries seem to have been artefacts of measurement error in the original data. It is likely that the formalism measure, which was discontinued by the World Bank after the first Doing Business report, suffered from similar systematic measurement error, and section 3 presents some initial evidence from four key jurisdictions suggesting that this was indeed the case, and that 
civil procedure is not more formalist in civil law countries than in common law countries either.

The World Bank data are conceptually limited. First, they are based on a particular reference scenario, and hence do not account for the whole spectrum of civil litigation handled by the courts. Second, the data are explicitly limited to courts of first instance, yet appeals can be a major factor particularly for duration, and as mentioned above are thought to be more frequent in civil law countries. Third, the data do not measure the quality of the ultimate judicial decision. It is therefore possible that the quality of civil procedure differs between common and civil law countries along dimensions not covered by the World Bank data. To address this possibility in as far as the available data allow, section 4 compares the enforceability of contracts in common and civil law countries using subjective analyst data. These data suggest that common law countries are performing better than French civil law countries, but worse than German and Scandinavian civil law countries.

Section 5 concludes by drawing out the implications of these findings for interpreting correlations between legal families and economic outcomes in other domains. Many such correlations have been documented in the "legal origins" literature, to which WORLD BANK [2004] and DJANKOV ET AL. [2003] belong.

Other papers revisiting early results of the legal origins literature with newer, more reliable data are Djankov, McLiesh, And Shleifer [2007] on creditor rights, and SPAMANN [2009a] on shareholder rights. The original civil procedure data, however, have not yet been reconsidered, and have been frequently used in the economic literature (e.g., ACEMOGLU AND JohnSON [2005]; BALAS ET AL. [2009]). HAYO AND VOIGT [2008] challenge the formalism index from a conceptual point of view and, using the original data, argue empirically that some formalist elements are beneficial for economic growth. KERN [2007] criticizes the crudeness of the original studies in comparison to the more nuanced yet purely qualitative comparative legal literature. DJANKOV ET AL. [2008] provide evidence of differences between common and civil law countries in a specialized area of procedure, bankruptcy.

Throughout, this paper uses the legal origin classification of LA PORTA ET AL. [2008], which updates previously used data by reassigning former socialist countries from socialist legal origin to French or German civil law. ${ }^{1}$

\footnotetext{
${ }^{1}$ The sample of LA PorTa ET AL. [2008] did not include Brunei, Kiribati, the Marshall
} 
The paper reports results using the natural logarithm of the variables from WORLD BANK [2009a]; unreported results with levels are similar.

\section{Complexity, duration, and cost}

This section introduces and analyzes the most recent World Bank data on complexity, duration, and cost. Subsection 1 describes the data and how they differ from earlier editions, which they explicitly supersede. Subsection 2 briefly comments on the interpretation of the complexity measure. Subsection 3 shows that neither complexity, duration, nor cost differ systematically by legal origin.

\subsection{Description of the data and of differences to earlier editions}

The "enforcement of contracts" section of the WORLD BANK's most recent Doing Business report [2009a] provides time series of procedural complexity, duration, and cost in courts of first instance for up to 181 countries in the years 2003-2008 (starting with 133 countries in 2003). The data refer to a standardized litigation scenario from filing of suit to execution of judgment: Briefly, plaintiff sues in the country's most populous city for payment of sold goods worth $200 \%$ of the country's GDP per capita; the defendant refuses payment on the grounds of inadequate quality; the judge decides fully in plaintiff's favor; there is no appeal. Based on this scenario, legal practitioners in each country annually answer tick-the-box questions for a long list of possible procedural steps, and provide estimates of the out-of-pocket cost and duration of various stages of the procedure (WORLD BANK [2008a]). In addition, the World Bank provides a public discussion forum for challenges to the data on its website. A World Bank team working exclusively on "enforcement of contracts" coordinates and verifies the responses through multiple interactions with the respondents, and distills the responses into three variables: total duration in days, total cost as a percentage of the claim value (i.e., indirectly as a percentage of GDP per capita), and the total number of required or usual procedural steps, which is referred to as complexity in this paper (cf. subsection 2.2 below).

Islands, and Timor-Leste, nor Serbia and Montenegro. For this paper, the first four countries instead took their legal origin classification from LA PORTA ET AL. [1999]. Serbia and Montenegro inherited their (French) legal origin from the former Yugoslavia. Palau, and West Bank and Gaza, are not classified. 
The current data not only extend but correct and explicitly supersede the data of earlier Doing Business reports (WorLd BANK [2008b], [2008c], [2009b]). Over the years, the World Bank weeded out measurement errors, ${ }^{2}$ and made small changes to the methodology to improve the variables' validity. ${ }^{3}$ In particular, it adapted the questionnaire to accommodate different ways of organizing the procedure, whose intricacies (GOLDSTEIN [1995]) were presumably underappreciated in the pioneering report. Between the 2008 and 2009 reports alone, $6 \%$ of the data were corrected (WORLD BANK [2009b]). The aggregate impact of the improvements since the original 2004 report can be gauged by the low rank correlations between the original Doing Business data and data for the same year (2003) from the most recent edition (WORLD BANK [2009a]) shown in table 1: .33 for complexity, .53 for duration, and .54 for cost.

Besides corrections properly speaking, the World Bank also made some slight modifications to the reference scenario that went beyond technical improvements. In particular, the current scenario postulates a claim for the price of delivered merchandise in the amount of $200 \%$ of GDP per capita, while the original scenario postulated a generic contractual claim in the amount of 50\% of GDP per capita (WorLD BAnK [2004], p. 109). These modifications seem too minor, however, to account for more than a very small part of the difference between the current and the original Doing Business data. This is particularly clear in comparison with the data collected in the background study to the first report, which refer to the eviction of a residential tenant and to the collection on a bounced check (in the amount of $5 \%$ of GNI per capita) (DJANKOV ET AL. [2003]). As table 1 shows, the rank correlations between corresponding variables from DJANKOV ET AL. [2003] and WORLD BANK [2004] are much higher than those between corresponding variables from WORLD BANK [2004] and WORLD BANK [2009a], even though the procedures underlying the former two data sets are much less similar to one another than those underlying the latter two. This pattern is

\footnotetext{
${ }^{2}$ For example, according to the original report (WORLD BANK [2004]), only seven days were supposed to pass between the filing of the suit and enforcement of the judgment in Tunisia (p. 42), and the entire procedure was supposed to cost only US $\$ 120$ in the USA (p. 46). By comparison, the corresponding, more realistic numbers in the current data set are 565 days and US $\$ 1,868$, respectively (WORLD BANK [2009a]).

3 "To provide a comparable time series for research, the data set is back-calculated to adjust for changes in methodology and any revisions in data due to corrections" (WORLD BANK $[2009 b])$.
} 
consistent with the idea that the first generation data contained correlated imperfections that were removed in subsequent revisions of the data; it is inconsistent with the idea that the first generation data were similarly reliable as the current data but differ because they refer to a (very slightly) different scenario.

\subsection{Interpretation and effects of complexity}

While the meaning of the duration and cost measures is straightforward, the meaning of the complexity measure is not. The measure conflates and equally weights disparate steps like the assignment of the case to a judge, mandatory mediation, the oral hearing or trial, and the court's notification of the parties that the written judgment is available in the courthouse (WORLD BANK [2008a]). These differ vastly in importance and length. Moreover, the simple summation of the steps gives equal weight to beneficial and detrimental requirements. Consequently, the measure would not distinguish between the optimal combination of steps and an even vastly inferior alternative as long as the overall number of steps is the same. Viewed in a practical perspective, policy makers who desire to reduce the complexity of civil procedure would not know which of the many steps of the procedure to eliminate - some of those steps, like the oral hearing, are presumably essential. If this is the case, what if anything can one learn from comparing the complexity scores of common and civil law countries?

It is likely, however, that all countries retain the essential steps of the procedure, and hence that variation in the complexity score results from additional steps of uncertain utility. If this were the case, regression results with the complexity score would reflect the value of these in-essential steps in the abstract, without pinning down precisely which steps matter. By contrast, if the complexity measure were noise, we would not expect to see any significant regression results.

Table 2 shows some support for the first view. The table shows estimates from levels (panel A) and first-difference (panel B) regressions of procedural quality (duration, cost, and the enforceability variable discussed in section 4.1 below) on complexity as the principal independent variable. These estimates suggest that at prevailing levels, procedural complexity as proxied by the number of steps is associated with substantially higher duration and perhaps higher cost, and lower perceived quality of contract enforcement in general. Assuming that the complexity variable is a valid measure of a relevant con- 
cept, the first-difference estimates can even be interpreted as evidence of a causal effect under some strong yet plausible assumptions (in particular, that rule changes have immediate effects, and do not anticipate shocks to the litigation system). As Jonathan Klick points out in his excellent comment, these estimates are fragile and need to be interpreted with caution. But at least they suggest that the World Bank's complexity measure may be on to something relevant, and deserves to be considered in the comparison of common and civil law countries in the next subsection.

\subsection{No correlation with legal origins}

Table 3 shows regressions of complexity, duration, and cost (country averages over 2003-2008) on legal origin with and without a control for the level of development (GDP per capita). Civil procedure in common law countries is more complex, protracted, and costly than in civil law countries taken as a whole (panel A), but less so than in French civil law countries considered separately (panel B). The differences are small, however, and statistically insignificant. Both common law countries and French civil law countries do worse than German and Scandinavian civil law countries, although controlling for GDP per capita, only the difference in complexity to the German civil law countries is statistically significant.

In principle, the difference between the results of table 3 and those reported in the earlier studies could be a timing effect - civil law countries might have had more complex, protracted, and costly litigation in 2003, but more than closed the gap by 2008. Indeed, table 4 shows that over the 20032008 time period, common law countries have been decreasing procedural complexity and duration at lower rates than civil law countries. ${ }^{4}$ Unreported tests with levels show that in 2003, civil procedure in common law countries was less complex and protracted than in civil law countries. The difference in 2003, however, was only about one quarter standard deviation and not statistically significant. Moreover, procedure in German and Scandinavian civil law countries was less complex and protracted than in common law countries already in 2003, even controlling for GDP per capita. In sum, based on the corrected data, there is no evidence of a difference between common and civil law countries at any point during the period 2003-2008.

\footnotetext{
${ }^{4}$ Estimates with the lagged level of the dependent variable as additional regressor, or without the control for changes in GDP per capita, are almost identical.
} 


\section{Formalism}

The initial Doing Business report (WoRLD BANK [2004]) and its background study (DJANKOV ET AL. [2003]) also found a strong correlation between legal origin and their "formalism index." ${ }^{5}$ This index was discontinued in subsequent reports. But if the early data gave an inaccurate picture of legal origin's role for complexity, duration, and cost, as documented in section 2 above, the formalism index from the same early data set is likely to suffer from similar shortcomings. Shedding light on this issue is important because the formalism index has been used in widely influential studies probing the role of legal origin. ${ }^{6}$

In the absence of comprehensive new data, the Appendix to this paper analyzes the formalism index for eviction procedures in 2003 in the three origin countries England, France, and Germany, as well as in the United States. $^{7}$ These are only four countries out of a population of about 200. As origin countries, however, they provide special leverage in the context of legal family comparisons and the theory of legal origins. The legal families span the world because "[t]he regulatory regimes of most developing countries are not indigenous - they are shaped by their colonial heritage" from the origin countries who "brought with them their laws and institutions" (WorLD BAnk [2004], p. xiv; cf. DJankov Et AL. [2003], p. 458). Hence if civil law countries as a whole were more formalist than common law countries, it should be because France and Germany are more formalist than England.

The numbers for evictions in 2003 derived in the Appendix, however, do not bear out such differences between the origin countries. Table 5 shows these numbers in comparison to the original numbers from DJANKOV ET AL. [2003]. It shows both the "formalism index" (net of the steps subindex) and the unweighted sum of its components; in each case, it shows formalism

\footnotetext{
${ }^{5}$ This index is the weighted sum of 28 binary indicators encoding deviations from a stylized informal procedure that commences without formalities such as written summons, does not involve legal professionals, is entirely oral, does not regulate the submission or evaluation of evidence, does not require legal justification of the parties' positions or the judge's decision, and does not allow appeals (WorLD BANK [2004], pp. 109-110). For more details, see DJANKov ET AL. [2003] (table 1) and the Appendix to this paper.

${ }^{6}$ E.g., Acemoglu and Johnson [2005]; Rosenthal and Voeten [2007]; Balas et AL. [2009].

${ }^{7}$ The US was added to the list of origin countries because owing to changes in English civil procedure, particularly recent ones, the US today corresponds more closely to the traditional common law model than England (Pound [1921]; STÜrner [2004]).
} 
not only as required by law (i.e., the legal minimum of formalist elements) but also as actually practiced in the courts (i.e., including formalist choices of judges and litigants). According to the revised weighted data, France is the most formalist, but Germany is the least formalist, and the differences are small, much smaller than in the original data. Moreover, the differences that do remain result from the weighting scheme, which is arbitrary. In the unweighted data, the countries are almost indistinguishable.

The Appendix identifies the index components for which its results differ from those of DJANKOV ET AL. [2003]. The source of the discrepancies cannot be traced further because DJANKOV ET AL. [2003] does not provide a detailed data documentation explaining its coding. By contrast, the Appendix to this paper explains all its coding decisions and documents all relevant legal source materials compliant with standards of legal writing. The information was compiled by an English barrister, a French law graduate, a German Assessor, and a New York attorney in many weeks of work. ${ }^{8}$

The analysis in the Appendix and its results shown in table 5 only refer to eviction proceedings. DJANKOV ET AL. [2003] also provided data for check collection proceedings, and WORLD BANK [2004] provided data for a simple contract dispute (see section 2.1 above). Eviction proceedings, however, are those for which these two studies found the greatest differences between common and civil law (as measured by a $t$-statistic). If these differences exist, they should have been visible here.

The argument for the special leverage of data from the origin countries implicitly assumed that differences present during the time their legal systems spread throughout the world persist to this day. It is possible that erstwhile differences between the origin countries diminished after decolonization (or even before) but persist in the former colonies (MERRYMAN [1996]). At least for formalism in small claims litigation as investigated here, however, this argument is not consistent with the historical record. The French revolution instituted a fully non-formalist small claims procedure (juges de paix) that remained in existence until the 1970s (FRICERO [2003]). By contrast, common law procedure was notoriously cumbersome, leading to the creation of small claims courts in common law jurisdictions starting only in the 1970s (Whelan [1990]). Many components of the formalism index such as the

\footnotetext{
${ }^{8}$ The latter three are the author of this paper. The French and the German compilation were also reviewed by a French and a German judge, respectively, who partially specialize in eviction proceedings.
} 
hearsay rule or the requirement for parties to cite applicable law are traditionally associated with common law, not civil law. ${ }^{9}$

In sum, the re-examination of the formalism index for the three origin countries and the United States, viewed against the background of the substantial systematic measurement error in the other three measures of the initial World Bank data set discussed in section 2 above, gives strong reason to doubt that civil procedure in civil law countries is more formalist than in common law countries, as the earlier studies had found.

\section{Other aspects of civil procedure}

So far, this paper has shown that measures of civil procedure constructed by the World Bank and affiliated researchers, and collected by the World Bank and in one instance (formalism) specifically for this paper, do not show systematic differences between common and civil law countries. As mentioned in the introduction, however, these measures are conceptually limited. In particular, they do not address appeals, which are believed to be more frequent in civil law countries and can be a major source of delay. Nor do they address the quality of judicial decisions. Unfortunately, data of comparable quality covering these aspects do not exist.

\subsection{BERI data on enforceability of contracts}

To get at least some handle on these other aspects of civil procedure, this paper follows DJANKOV ET AL. [2003] and uses a subjective measure of the enforceability of contracts from Business Environment Risk Intelligence (BERI), a U.S.-based commercial provider. As part of an overall country risk measure provided to potential foreign investors, BERI assesses whether contracting partners in 98 countries generally honor contracts, and whether authorities apply and enforce laws facilitating this. ${ }^{10}$ Any shortcomings of a

\footnotetext{
${ }^{9}$ The traditional civil law attitude is expressed in the maxims "da mi factum, dabo tibi ius" (give me the facts, I will give you the law) and "curia novit ius" (the court knows the law); the traditional common law attitude is the opposite (MANN [1977]).

${ }^{10}$ The precise questions were (email from BERI to the author of March 11, 2009)

"1. Does the party generally honor both the terms of the contract and the process of enforcement within the country during the contract's duration or for an extended period of time when no time limit is involved?;

"2. Do authorities apply/enforce laws and regulations that motivate the party with whom you have the contract to honor the contract's terms?"
} 
country's civil procedure system should be reflected in this measure, possibly confounded with extralegal enforcement mechanisms.

Table 6 shows results from regressing enforceability of contracts in 2003 on legal families and, depending on specification, the level of development (GDP per capita), a dummy for transition countries, and Transparency International's Corruption Perception Index (rescaled). The BERI data are rescaled to have mean zero and a standard deviation of one, and to be increasing in quality.

Unlike the more objective data discussed in the previous two sections, the enforceability data do show some systematic difference between common and civil law countries. On average, enforceability is one third of a standard deviation lower in civil law countries, although this estimate is noisy $(t=1.6)$ (model 1). Controlling for the level of development, the difference grows to half a standard deviation and becomes highly statistically significant, whether or not one controls for the status of transition countries $(t>3.2)$ (models 3 and 5). A comparison of these estimates with model 7 suggests that about half of this differential between common and civil law countries is explained by higher corruption in civil law countries.

The full picture is, however, more complicated. As models 2, 4, and 6 show, the differences between common and civil law countries are driven by the French civil law countries. By contrast, the German and Scandinavian civil law countries do even better than the common law countries (model 2 ). It is true that controlling for GDP per capita, the common law mean is higher than the German mean $(t=1.67)$ (model 4$)$. On the other hand, the conditional means are identical if one also accounts for the special circumstances of transition countries (model 6), many of which are today counted as belonging to the German civil law family. The Scandinavian countries do better than common law countries regardless of controls.

The full pattern emerging from these data is therefore not that common law countries receive higher subjective enforceability evaluations than civil law countries, but that the French civil law countries receive lower evaluations than all other groups. It is also possible that these results have nothing to do with civil procedure per se but with other factors influencing the enforceability of contracts. At a minimum, however, these data reinforce the initial observation that relevant legal family differences may exist in areas

Some further details about BERI's assembly of the data can be found at http://www.beri.com/brs.asp. 
and dimensions of civil procedure not covered by the Doing Business data.

\subsection{WBES data on consistency and confidence in the legal system}

Another source of subjective procedural quality measures used in DJANKOV ET AL. [2003] is the World Bank's World Business Environment Survey (WBES) of over 10,000 businesspeople in 80 jurisdictions between 1998 and 2000. The WBES contained questions on the consistency of, and confidence in, the country's dispute resolution system. By these measures, common law judiciaries perform significantly better than civil law jurisdictions except the Scandinavians (unreported).

The measures are suspect for various reasons though. First, it appears that correspondents were not chosen by random sampling. Second, major patterns in the data are implausible - for example, the level of development (GDP per capita) explains only $6 \%$ of the variation of the consistency measure, and the five countries with the most consistent dispute resolution are supposed to be Botswana, Egypt, Namibia, Tunisia, and, more credibly, Singapore, far ahead of countries such as Canada, France, Germany, the UK, or the United States. Third, to the extent that other WBES procedure measures can be compared to more objective measures from other sources, the comparison suggests that the WBES data are mostly noise: as shown in table 7, WBES measures of affordability and speed are hardly correlated with cost and duration, respectively, as measured by WORLD BANK [2004], [2009a] (2003 data) or DJANKov ET AL. [2003], [2008].

\section{Conclusion: Legal origins?}

This paper shed doubt on the empirical claim that civil procedure is more complex and formalist and therefore less efficient in civil law countries than in common law countries. The best quality data - complexity, duration, and cost from WORLD BANK [2009a] - show no difference between common and civil law countries. These data revise and supersede some of the very data that gave rise to the claim in the first place (WORLD BANK [2004]). Formalism data from the same first generation data set might be open to similar revisions but were discontinued by the World Bank. Consistent with this suspicion, new hand-collected data on formalism in four origin jurisdictions show little evidence of a common/civil law split, unlike the original data. Since these four origin countries are the source of much of the law of 
other countries in the world, the finding suggests that accurately measured formalism would not be higher in civil law jurisdictions than in common law jurisdictions either.

The only indication that common law countries might have superior civil procedure systems comes from subjective data on the enforceability of contracts, which provide a broader picture of civil procedure. At the same time, German and Scandinavian civil law countries seem to do even better than common law countries by this measure, which may also confound civil procedure with extralegal enforcement mechanisms. Still, these data underline the possibility that economically meaningful legal family differences may exist in areas and dimensions of civil procedure not covered by the high quality World Bank data. In this connection, it is noteworthy that DJANKOV ET AL. [2008] have recently documented significant differences between legal families in a more specialized branch of procedure, bankruptcy.

If confirmed, the lack of differences between common and civil law countries at least in courts of first instance would be remarkable in itself. As mentioned in the introduction, the historical divergence of common law and civil law started in civil procedure and remains most pronounced there today. It is true that the evidence presented in this paper does not directly address what are traditionally considered the key differences between common and civil law procedure, such as the role of the judge in the administration of evidence, the schedule of the trial or process, and, most regrettably, the role of appeals. The evidence does suggest, however, that these structural differences, if they are indeed systematic, do not have repercussions on the measurable quality of civil procedure, at least in the standard contract litigation scenario covered by the Doing Business data, which does not allow for appeals.

The findings of this paper are also relevant for interpreting differences between common and civil law countries in other domains ranging from investor protection to military conscription, which have been documented in the legal origins literature (LA PORTA ET AL. 2008). To start, some studies in this field have used the procedural indicators of WORLD BANK [2004] and DJANKOV ET AL. [2003] to disentangle the effects of different institutions and their historic causes (e.g., Acemoglu And Johnson [2005]; BeCK, DemirgüÇ-Kunt, and Levine [2003]; Rosenthal and Voeten [2007]). The results of these studies might differ with revised data.

More generally, if the historical common/civil law division does not manifest itself economically meaningfully in the area where it originates, it is 
unlikely to explain differences in much more remote areas. Rules and outcomes in areas such as military conscription may be correlated with legal families (Mulligan and Shleifer [2005]), but the explanation for this need not reside in historical differences between common and civil law. ${ }^{11}$ The legal families are largely congruent with the (former) spheres of influence of different European powers, who differ by more than the "origin" of their legal system in the common or civil law. For example, Rostowski AND Stacescu [2006] explain differences in growth outcomes between former English and French colonies with different colonial education policies rather than differences of the legal regime. Spamann [2009b] shows that today the former colonies continue to import regulatory blueprints from their respective former colonizers for reasons that seem to have little to do with "intrinsic" differences of common and civil law. At home, England historically differed from France and other European countries on more than the legal dimension, and many theories attempting to explain why today's Anglo-Saxon countries are more market-oriented than Continental European ones do not invoke differences between common and civil law (e.g., ESPING-ANDERSEN [1990]; Hall and Soskice [2001]; Roe [2006]). The question will surely continue to generate exciting research. This paper suggests, however, that civil procedure is probably not the right place to look for an answer.

\section{References}

Acemoglu, D., And S. Johnson [2005], "Unbundling Institutions," Journal of Political Economy, 113, 949-995.

Balas, A., R. La Porta, F. Lopez-De-Silanes, and A. Shleifer [2009], "The Divergence of Legal Procedures," American Economic Journal: Economic Policy, forthcoming.

Beck, T., A. DemirgüÇ-Kunt, And R. Levine [2003], "Law and finance: why does legal origin matter?," Journal of Comparative Economics, 31, 653-675.

Caenegem, R.C. van [1988], The birth of the English common law, 2nd ed., Cambridge University Press: Cambridge and New York.

Dawson, J.P. [1968], The Oracles of the Law, University of Michigan Law School: Ann Arbor.

\footnotetext{
${ }^{11}$ This view now seems to be shared by LA PORTA ET AL. [2008] themselves, who characterize (p. 286) "legal origin as a style of social control of economic life (and maybe other aspects of life as well)."
} 
Djankov, S., O. Hart, C. McLiesh, And A. Shleifer [2008], "Debt Enforcement Around the World," Journal of Political Economy, 116, 1105-1149.

Djankov, S., C. McLiesh, And A. Shleifer [2007], "Private Credit in 129 Countries," Journal of Financial Economics, 84, 299-329.

Djankov, S., R. La Porta, F. Lopez-De-Silanes, and A. Shleifer [2003], "Courts," Quarterly Journal of Economics, 118, 453-517.

Esping-Andersen, G. [1990], The Three Worlds of Welfare Capitalism, Princeton University Press: Princeton.

Fricero, N. [2003], "Tribunaux d'Instance," 9 pp. in: Répertoire de Procédure Civile Dalloz, Vol. 5, Dalloz: Paris.

Goldstein, S. [1995], "On Comparing and Unifying Civil Procedural Systems," pp. 1-43, in: R. Cotterrell (ed.), Butterworth Lectures 1994: Process and Substance, Butterworths: London.

Hall, P., And D. Soskice [2001], "An Introduction to Varieties of Capitalism," pp. 1-68 in: P. Hall and D. Soskice (eds.), Varieties of Capitalism: the institutional foundations of comparative advantage, Oxford University Press: Oxford and New York.

Hayo, B., and S. Voigt [2008], "The Relevance of Judicial Procedure for Economic Growth," CESifo Working Paper 2514, Munich.

Kern, C. [2007], Civil Procedure between Simplification and Formalism, Mohr Siebeck: Tübingen.

La Porta, R., F. Lopez-De-Silanes, And A. Shleifer [2008], "The Economic Consequences of Legal Origin," Journal of Economic Literature, 46(2), 285332 .

--, And R. Vishny [1999], "The Quality of Government," Journal of Law, Economics, and Organization, 15, 222-279.

Mann, F.A. [1977], "Fusion of the Legal Professions?," Law Quarterly Review, 93, 367-377.

Merryman, J. [1996], "The French Deviation," American Journal of Comparative Law, 44, 109-119.

Mulligan, C., And A. Shleifer [2005], "Conscription as Regulation," American Law and Economics Review, 7, 85-111.

Pound, R. [1921], The Spirit of the Common Law, Marshall Jones: Boston.

Roe, M. [2006], "Legal Origins, Politics, and Modern Stock Markets," Harvard Law Review, 120, 460-527.

Rosenthal, H., and E. Voeten [2007], "Measuring Legal Systems," Journal of Comparative Economics, 35, 711-728. 
Rostowski, J., And B. Stacescu [2006], "The Wig and the Pith Helmet - the Impact of 'Legal School' versus Colonial Institutions on Economic Performance (second version)," Working paper, Center for Social and Economic Research, Warsaw.

Spamann, H. [2009a], "The 'Antidirector Rights Index' Revisited," Review of Financial Studies, forthcoming.

- - [2009b], "Contemporary Legal Transplants - Legal Families and the Diffusion of (Corporate) Law," Brigham Young University Law Review, forthcoming.

StÜrner, R. [2004], "Procedural Law and Legal Cultures," pp. 9-30 in: P. Gilles and T. Pfeiffer (eds.), Procedural Law and Legal Cultures - Inaugural Speech and German National Reports for the World Conference on Procedural Law in Mexico City, Mexico, 2003, Nomos: Baden-Baden.

Whelan, C. [1990], "Small Claims Courts: Heritage and Adjustment," pp. 207234 in: C. Whelan (ed.), Small Claims Courts - A Comparative Study, Clarendon Press: Oxford.

World Bank [2004], Doing Business in 2004 - Understanding Regulation, The World Bank and Oxford University Press: Washington D.C.

- - [2008a], "Survey instrument for 'Enforcing Contracts'," http://www.doingbusi ness.org/Documents/Survey_Instruments/EC_2008_Eng.pdf.

- - [2008b], Doing Business: An Independent Evaluation - Taking the Measure of the World Bank-IFC Doing Business Indicators, The World Bank: Washington D.C.

- - [2008c], "Changes to the Methodology, 2004-2007," http://www.doingbusi ness.org/MethodologySurveys/MethodologyNoteArchive.aspx.

- - [2009a], Doing Business in 2009, The World Bank and the International Finance Corporation: Washington D.C.

- - [2009b], "Changes in the Methodology 2008," http://www.doingbusiness .org/ MethodologySurveys/MethodologyNote.aspx.

Zweigert, K., And H. Kötz [1998], Introduction to Comparative Law, 3rd ed., Clarendon Press: Oxford; Oxford University Press: New York. 
Table 1: Corresponding variables (2003 values): Spearman's $\rho$

\begin{tabular}{lllll}
\hline \hline steps & WB (2009) & WB (2004) & DLLS(c) & DLLS(e) \\
\hline WB (2009) & 1 & & & \\
WB (2004) & 0.33 & 1 & & \\
DLLS(c) & 0.25 & 0.83 & 1 & \\
DLLS(e) & 0.11 & 0.74 & 0.84 & 1 \\
\hline \hline days & WB (2009) & WB (2004) & DLLS(c) & DLLS(e) \\
\hline WB (2009) & 1 & & & \\
WB (2004) & 0.53 & 1 & & \\
DLLS(c) & 0.47 & 0.81 & 1 & \\
DLLS(e) & 0.32 & 0.45 & 0.50 & 1 \\
\hline \hline cost & WB (2009) & WB (2004) & DLLS(c) & DLLS(e) \\
\hline WB (2009) & 1 & & & \\
WB (2004) & 0.54 & 1 & & \\
\hline \hline formalism & WB (2009) & WB (2004) & DLLS(c) & DLLS(e) \\
\hline WB (2004) & & 1 & & \\
DLLS(c) & & 0.90 & 1 & \\
DLLS(e) & & 0.82 & 0.83 & 1 \\
\hline \hline
\end{tabular}

WB $=$ World Bank; DLLS $=$ Djankov et al. (2003)

$\mathrm{c}=$ check collection $; \mathrm{e}=$ eviction 
Table 2: The effects of complexity

\begin{tabular}{|c|c|c|c|c|c|c|}
\hline & $\begin{array}{c}(1) \\
\ln (\text { days })\end{array}$ & $\begin{array}{c}(2) \\
\ln (\text { days }) \\
\end{array}$ & $\begin{array}{c}(3) \\
\ln (\text { cost })\end{array}$ & $\begin{array}{c}(4) \\
\ln (\text { cost })\end{array}$ & $\begin{array}{c}(5) \\
\ln (\text { cost })\end{array}$ & $\begin{array}{c}(6) \\
\text { enforce }\end{array}$ \\
\hline & \multicolumn{6}{|c|}{ Panel A: Levels } \\
\hline $\ln ($ steps $)$ & $\begin{array}{c}0.90^{* * *} \\
(0.21)\end{array}$ & $\begin{array}{c}0.82^{* * *} \\
(0.24)\end{array}$ & $\begin{array}{l}0.50^{*} \\
(0.26)\end{array}$ & $\begin{array}{l}-0.30 \\
(0.23)\end{array}$ & $\begin{array}{l}-0.19 \\
(0.20)\end{array}$ & $\begin{array}{c}-1.22^{* * *} \\
(0.31)\end{array}$ \\
\hline $\ln (\mathrm{GDP}$ pc $)$ & & $\begin{array}{l}-0.03 \\
(0.03)\end{array}$ & & $\begin{array}{c}-0.30^{* * *} \\
(0.04)\end{array}$ & $\begin{array}{c}-0.29^{* * *} \\
(0.04)\end{array}$ & $\begin{array}{c}0.63^{* * *} \\
(0.06)\end{array}$ \\
\hline Year & $\begin{array}{c}0.00 \\
(0.01)\end{array}$ & $\begin{array}{c}0.00 \\
(0.01)\end{array}$ & $\begin{array}{l}-0.01 \\
(0.01)\end{array}$ & $\begin{array}{l}-0.01 \\
(0.01)\end{array}$ & $\begin{array}{c}0.01 \\
(0.01)\end{array}$ & \\
\hline Constant & $\begin{array}{c}0.78 \\
(9.25)\end{array}$ & $\begin{array}{l}-1.86 \\
(11.4)\end{array}$ & $\begin{array}{c}30.1 \\
(20.7)\end{array}$ & $\begin{array}{l}19.8 \\
(26.4)\end{array}$ & $\begin{array}{l}-3.20 \\
(12.7)\end{array}$ & $\begin{array}{l}-1.32 \\
(1.41)\end{array}$ \\
\hline$N$ & 970 & 747 & 970 & 747 & 743 & 88 \\
\hline$J$ & 181 & 169 & 181 & 169 & 168 & 88 \\
\hline \multirow[t]{2}{*}{$R^{2}$} & 0.12 & 0.12 & 0.02 & 0.30 & 0.37 & 0.70 \\
\hline & \multicolumn{6}{|c|}{ "Panel B: First differences } \\
\hline $\ln$ (steps) & $\begin{array}{c}1.38^{* * *} \\
(0.41)\end{array}$ & $\begin{array}{c}1.40^{* * * *} \\
(0.45)\end{array}$ & $\begin{array}{c}0.10 \\
(0.22)\end{array}$ & $\begin{array}{c}0.20 \\
(0.22)\end{array}$ & $\begin{array}{c}0.36^{* *} \\
(0.15)\end{array}$ & \\
\hline $\ln (\mathrm{GDP} p c)$ & & $\begin{array}{l}-0.01 \\
(0.05)\end{array}$ & & $\begin{array}{l}-0.22 \\
(0.21)\end{array}$ & $\begin{array}{l}-0.02 \\
(0.04)\end{array}$ & \\
\hline Constant & $\begin{array}{c}-0.004^{* * *} \\
(0.001)\end{array}$ & $\begin{array}{c}-0.006^{* *} \\
(0.003)\end{array}$ & $\begin{array}{l}-0.009 \\
(0.009)\end{array}$ & $\begin{array}{l}-0.004 \\
(0.005)\end{array}$ & $\begin{array}{l}-0.000 \\
(0.001)\end{array}$ & \\
\hline$N$ & 789 & 578 & 789 & 578 & 575 & \\
\hline$J$ & 181 & 167 & 181 & 167 & 166 & \\
\hline$R^{2}$ & 0.13 & 0.15 & 0.00 & 0.00 & 0.02 & \\
\hline
\end{tabular}

Model 5 omits Bhutan, which accounts for $98 \%$ of the variance of $\Delta \ln (\operatorname{cost})$

"enforce" is enforceability of contracts in 2003 from BERI

GDP per capita data for 2003-2007 are PPP-adjusted and come from WDI online

All other data are for 2003-2008 (model 6: 2003 only) and come from World Bank (2009)

Country-clustered robust standard errors in parentheses

${ }^{*} p<.1,{ }^{* *} p<.05,{ }^{* * *} p<.01$ 
Table 3: Legal origin and procedural complexity, duration, and cost

\begin{tabular}{|c|c|c|c|c|c|c|}
\hline & $\begin{array}{c}(1) \\
\ln (\text { steps })\end{array}$ & $\begin{array}{c}(2) \\
\ln (\text { steps }) \\
\end{array}$ & $\begin{array}{c}(3) \\
\ln (\text { days }) \\
\end{array}$ & $\begin{array}{c}(4) \\
\ln (\text { days })\end{array}$ & $\begin{array}{c}(5) \\
\ln (\text { cost }) \\
\end{array}$ & $\begin{array}{c}(6) \\
\ln (\text { cost }) \\
\end{array}$ \\
\hline & \multicolumn{6}{|c|}{ Panel A: common law vs. civil law } \\
\hline Civil law & $\begin{array}{l}-0.02 \\
(0.03)\end{array}$ & $\begin{array}{l}-0.00 \\
(0.03)\end{array}$ & $\begin{array}{l}-0.01 \\
(0.08)\end{array}$ & $\begin{array}{l}-0.02 \\
(0.08)\end{array}$ & $\begin{array}{l}-0.04 \\
(0.10)\end{array}$ & $\begin{array}{l}-0.02 \\
(0.08)\end{array}$ \\
\hline $\ln (\mathrm{GDP}$ pc $)$ & & $\begin{array}{c}-0.05^{* * *} \\
(0.01)\end{array}$ & & $\begin{array}{c}-0.08^{* * *} \\
(0.03)\end{array}$ & & $\begin{array}{c}-0.27^{* * *} \\
(0.03)\end{array}$ \\
\hline Constant & $\begin{array}{c}3.64 \\
(0.02)\end{array}$ & $\begin{array}{c}4.08 \\
(0.09)\end{array}$ & $\begin{array}{c}6.32 \\
(0.06)\end{array}$ & $\begin{array}{c}7.05 \\
(0.25)\end{array}$ & $\begin{array}{c}3.35 \\
(0.08)\end{array}$ & $\begin{array}{c}5.69 \\
(0.27)\end{array}$ \\
\hline$R^{2}$ & 0.00 & 0.15 & 0.00 & 0.05 & 0.00 & 0.33 \\
\hline \multirow[t]{2}{*}{$N$} & 179 & 169 & 179 & 169 & 179 & 169 \\
\hline & \multicolumn{6}{|c|}{ Panel B: common law vs. civil law subgroups } \\
\hline French & $\begin{array}{c}0.02 \\
(0.03)\end{array}$ & $\begin{array}{c}0.02 \\
(0.03)\end{array}$ & $\begin{array}{c}0.06 \\
(0.08)\end{array}$ & $\begin{array}{c}0.02 \\
(0.08)\end{array}$ & $\begin{array}{c}0.07 \\
(0.10)\end{array}$ & $\begin{array}{c}0.02 \\
(0.09)\end{array}$ \\
\hline German & $\begin{array}{c}-0.13^{* * *} \\
(0.05)\end{array}$ & $\begin{array}{l}-0.09^{*} \\
(0.04)\end{array}$ & $\begin{array}{l}-0.21^{*} \\
(0.12)\end{array}$ & $\begin{array}{l}-0.16 \\
(0.13)\end{array}$ & $\begin{array}{c}-0.40^{* * *} \\
(0.15)\end{array}$ & $\begin{array}{l}-0.16 \\
(0.14)\end{array}$ \\
\hline Scandinavian & $\begin{array}{c}-0.21^{* *} \\
(0.08)\end{array}$ & $\begin{array}{l}-0.11 \\
(0.08)\end{array}$ & $\begin{array}{c}-0.44^{* *} \\
(0.22)\end{array}$ & $\begin{array}{l}-0.33 \\
(0.23)\end{array}$ & $\begin{array}{c}-0.74^{* * *} \\
(0.28)\end{array}$ & $\begin{array}{l}-0.25 \\
(0.25)\end{array}$ \\
\hline $\ln (\mathrm{GDP}$ pc $)$ & & $\begin{array}{c}-0.04^{* * *} \\
(0.01)\end{array}$ & & $\begin{array}{c}-0.06^{* *} \\
(0.03)\end{array}$ & & $\begin{array}{c}-0.25^{* * *} \\
(0.03)\end{array}$ \\
\hline Constant & $\begin{array}{c}3.64 \\
(0.02)\end{array}$ & $\begin{array}{c}3.99 \\
(0.09)\end{array}$ & $\begin{array}{c}6.32 \\
(0.06)\end{array}$ & $\begin{array}{c}6.85 \\
(0.26)\end{array}$ & $\begin{array}{c}3.35 \\
(0.08)\end{array}$ & $\begin{array}{c}5.53 \\
(0.29)\end{array}$ \\
\hline$R^{2}$ & 0.09 & 0.19 & 0.05 & 0.08 & 0.09 & 0.34 \\
\hline$N$ & 179 & 169 & 179 & 169 & 179 & 169 \\
\hline $\begin{array}{l}\text { The data are } \mathrm{cc} \\
\text { The legal origin } \\
\text { GDP per capita } \\
\text { All other data } \\
\text { OLS standard } \\
{ }^{*} p<.1,{ }^{* *} p<\end{array}$ & $\begin{array}{l}\text { untry avera } \\
\text { classificatic } \\
\text { data are } \mathrm{P} \\
\text { re from Wo } \\
\text { crors in par } \\
.05,{ }^{* * *} p\end{array}$ & $\begin{array}{l}\text { es for the p } \\
\text { is from La } \\
\text { P-adjusted } \\
\text { ld Bank (20 } \\
\text { ntheses } \\
.01\end{array}$ & $\begin{array}{l}\text { Poriod 2003-2 } \\
\text { Porta et al } \\
\text { and come f } \\
\text { 99) }\end{array}$ & $\begin{array}{l}008 \text { (mode } \\
(2008) \\
\text { om WDI o }\end{array}$ & $\begin{array}{l}2,4, \text { and } 6 \\
\text { line }\end{array}$ & $2003-2007$ \\
\hline
\end{tabular}


Table 4: Legal-origin specific time trends 2003-2007

\begin{tabular}{|c|c|c|c|c|c|c|}
\hline & $\begin{array}{c}(1) \\
\Delta \ln (\text { steps })\end{array}$ & $\begin{array}{c}(2) \\
\Delta \ln (\text { steps })\end{array}$ & $\begin{array}{c}(3) \\
\Delta \ln (\text { days })\end{array}$ & $\begin{array}{c}(4) \\
\Delta \ln (\text { days })\end{array}$ & $\begin{array}{c}(5) \\
\Delta \ln (\text { cost })\end{array}$ & $\begin{array}{c}(6) \\
\Delta \ln (\cos \mathrm{t})\end{array}$ \\
\hline Civil law & $\begin{array}{c}-0.0025^{* *} \\
(0.0013)\end{array}$ & & $\begin{array}{l}-0.0043 \\
(0.0040)\end{array}$ & & $\begin{array}{c}0.0406 \\
(0.0431)\end{array}$ & \\
\hline French & & $\begin{array}{c}-0.0022^{*} \\
(0.0013)\end{array}$ & & $\begin{array}{l}-0.0031 \\
(0.0042)\end{array}$ & & $\begin{array}{c}0.0399 \\
(0.0426)\end{array}$ \\
\hline German & & $\begin{array}{c}-0.0047^{* *} \\
(0.0021)\end{array}$ & & $\begin{array}{l}-0.0101 \\
(0.0072)\end{array}$ & & $\begin{array}{c}0.0461 \\
(0.0474)\end{array}$ \\
\hline Scandinavian & & $\begin{array}{c}0.0001 \\
(0.0012)\end{array}$ & & $\begin{array}{l}-0.0034 \\
(0.0089)\end{array}$ & & $\begin{array}{c}0.0315 \\
(0.0387)\end{array}$ \\
\hline$\Delta \ln (\mathrm{GDP}$ pc $)$ & $\begin{array}{c}-0.0124 \\
(0.0144)\end{array}$ & $\begin{array}{c}-0.0077 \\
(0.0134)\end{array}$ & $\begin{array}{c}-0.0287 \\
(0.0522)\end{array}$ & $\begin{array}{l}-0.0184 \\
(0.0521)\end{array}$ & $\begin{array}{c}-0.2852 \\
(0.2603)\end{array}$ & $\begin{array}{c}-0.2981 \\
(0.2693)\end{array}$ \\
\hline Constant & $\begin{array}{c}0.0002 \\
(0.0013)\end{array}$ & $\begin{array}{c}0.0001 \\
(0.0013)\end{array}$ & $\begin{array}{c}-0.0049 \\
(0.0046)\end{array}$ & $\begin{array}{l}-0.0053 \\
(0.0046)\end{array}$ & $\begin{array}{l}-0.0309 \\
(0.0323)\end{array}$ & $\begin{array}{l}-0.0305 \\
(0.0321)\end{array}$ \\
\hline$N$ & 578 & 578 & 578 & 578 & 578 & 578 \\
\hline$J$ & 167 & 167 & 167 & 167 & 167 & 167 \\
\hline$R^{2}$ & 0.009 & 0.014 & 0.002 & 0.005 & 0.005 & 0.005 \\
\hline
\end{tabular}

The legal origin classification is from La Porta et al. (2008)

GDP per capita data are PPP-adjusted and come from WDI online

All other data are from World Bank (2009)

Country-clustered standard errors in parentheses

${ }^{*} p<.1,{ }^{* *} p<.05,{ }^{* * *} p<.01$

Table 5: Formalism index for evictions (2003) (net of steps subindex)

\begin{tabular}{llllll}
\hline \hline \multirow{2}{*}{ weighted } & DE & FR & GB & US \\
& DJANKOV ET AL. [2003] & 3.38 & 3.54 & 2.08 & 2.75 \\
& Law-on-books & 1.83 & 2.76 & 2.33 & 2.42 \\
& Practice & 2.37 & 2.96 & 2.53 & 2.62 \\
\hline \multirow{2}{*}{ unweighted } & DJANKOV ET AL. [2003] & 17 & 15 & 10 & 12 \\
& Law-on-books & 8 & 11 & 10.25 & 11 \\
& Practice & 11.5 & 12 & 11 & 12 \\
\hline \hline
\end{tabular}


Table 6: Legal origin and the enforceability of contracts

\begin{tabular}{lcccccccc}
\hline \hline & $(1)$ & $(2)$ & $(3)$ & $(4)$ & $(5)$ & $(6)$ & $(7)$ & $(8)$ \\
\hline Civil law & -0.36 & & $-0.51^{* * *}$ & & $-0.45^{* * *}$ & & $-0.21^{*}$ & \\
& $(0.22)$ & & $(0.13)$ & & $(0.14)$ & & $(0.11)$ & \\
French & & $-0.67^{* * *}$ & & $-0.62^{* * *}$ & & $-0.55^{* * *}$ & & $-0.23^{* *}$ \\
& & $(0.21)$ & & $(0.13)$ & & $(0.13)$ & & $(0.11)$ \\
German & & 0.23 & & $-0.30^{*}$ & & -0.03 & & 0.13 \\
& & $(0.28)$ & & $(0.18)$ & & $(0.21)$ & & $(0.17)$ \\
Scandinav. & & $1.22^{* *}$ & & 0.21 & & 0.25 & & -0.32 \\
& & $(0.47)$ & & $(0.30)$ & & $(0.30)$ & & $(0.25)$ \\
$\ln$ (GDP pc) & & & $0.71^{* * *}$ & $0.65^{* * *}$ & $0.70^{* * *}$ & $0.62^{* * *}$ & $0.20^{* * *}$ & $0.16^{* *}$ \\
& & & $(0.05)$ & $(0.05)$ & $(0.05)$ & $(0.05)$ & $(0.07)$ & $(0.08)$ \\
Transition & & & & & -0.21 & $-0.37^{* *}$ & -0.01 & -0.18 \\
& & & & & $(0.15)$ & $(0.16)$ & $(0.12)$ & $(0.13)$ \\
Corruption & & & & & & & $-0.29 * * *$ & $-0.29^{* * *}$ \\
& & & & & & & $(0.03)$ & $(0.04)$ \\
Constant & 0.26 & 0.26 & -6.01 & -5.49 & -5.94 & -5.23 & -0.02 & 0.31 \\
& $(0.19)$ & $(0.17)$ & $(0.47)$ & $(0.48)$ & $(0.47)$ & $(0.48)$ & $(0.82)$ & $(0.84)$ \\
\hline$N$ & 98 & 98 & 95 & 95 & 95 & 95 & 93 & 93 \\
$R^{2}$ & 0.03 & 0.24 & 0.69 & 0.72 & 0.69 & 0.73 & 0.82 & 0.83 \\
\hline \hline
\end{tabular}

The dependent variable is enforceability of contracts in 2003 from BERI

The legal origin classification is from La Porta et al. (2008)

GDP per capita data for 2003 are PPP-adjusted and come from WDI online)

"Transition" is socialist legal origin from La Porta et al. (1999)

"Corruption" is 10 minus Transparency International's Corruption Perception Index 2003

OLS standard errors in parentheses

${ }^{*} p<.1,{ }^{* *} p<.05,{ }^{* * *} p<.01$

Table 7: WBES and objective measures: Spearman's $\rho$

\begin{tabular}{lccccc}
\hline \hline & WB (2009) & WB (2004) & DLLS(c) & DLLS(e) & DHMS \\
\hline quick / days & -.34 & -.38 & -.49 & -.36 & -.27 \\
affordable / cost & -.06 & .01 & & & -.01 \\
\hline \hline WB = World Bank; DLLS = Djankov et al. (2003); DHMS = Djankov et al. (2008) \\
$\mathrm{c}=$ check collection; e = eviction
\end{tabular}




\section{APPENDIX TO \\ “Legal Origins, Civil Procedure, And the Quality of Contract ENFORCEMENT”}

This Appendix analyzes the law applicable to an eviction procedure in England, France, Germany, and the USA with a view to generating, for these countries, values on the "formalism index", as defined in Djankov et al. (2003) with additional clarifications from World Bank (2004). ${ }^{1}$

The preliminary Part I provides more detail on the hypothetical case under consideration and discusses how this Appendix deals with ambiguities of variable definitions in general, and with discretionary choices of the parties and the judge in the procedure in particular. Part II successively considers each of the seven subindices of the "formalism index". Part III discusses aggregate index values under different weighting and coding schemes. The results are summarized numerically in comparison to values of Djankov et al. (2003) in the table at the end of this Appendix (which also reproduces the index component definitions); the text presents the explanations and references behind those numbers.

The English data were initially compiled by Sarah Ford.

${ }^{1}$ Relevant statutes, cases, and other materials are cited according to local convention. 


\section{PRELIMINARY REMARKS}

\section{A. More details on the hypothetical case under consideration}

As mentioned above, and following Djankov et al. (2003), the hypothetical case under consideration is an eviction proceeding by the landlord against a residential tenant for failure to pay rent in the most populous city in every jurisdiction, i.e., Paris, Berlin, London, and New York City for France, Germany, England, and the US, respectively. The choice of city is very important for the US, since the relevant procedure is regulated by state law. In what follows, this Appendix therefore generally refers to New York law for short.

Note in this connection that England and New York City provide special procedures for eviction claims: the possession claim under CPR Part 55 in England, and the non-payment variant of the summary proceeding to recover possession of real property under RPAPL $\S 732$ in New York City. ${ }^{2}$

To match the other data in World Bank (2004) (Djankov et al. 2003 do not provide a reference date), this Appendix generally refers to the law in force in 2003, but also mentions changes in the immediately preceding years in the footnotes.

Many details of the case facts and litigants' and judges' behavior bear on the index values. Djankov et al. (2003, 460) specify that the parties do not settle, and that compliance with the judgment is not voluntary. To fill in remaining gaps, the present discussion relies on further details provided in World Bank (2004). These include, in particular, that each party attempts to call one witness, that the claimant is $100 \%$ right, and that the court decides every motion for the claimant and grants the claimant's claim in its entirety (109).

\section{B. Choices by parties and judges}

Unfortunately, the details provided in Djankov et al. (2003) and World Bank (2004) do not address all relevant issues, even assuming that unusual moves do not happen, such as a request for the disqualification of a judge, or, in New York, for a jury trial.

In particular, the law often grants the parties and/or the judge the choice between "formalist" and "non-formalist” alternatives. For example, English parties can choose whether to introduce written witness statements in advance of trial ("formalist”), or oral witness testimony at trial ("non-formalist"). Similarly, German judges can choose whether to request a written opposition by the respondent or not ("formalist" and "non-formalist", respectively). Which alternative should determine the country's index value?" ${ }^{3}$ The general approach of this Appendix is to consider both the most "non-formalist" option provided by the law, and, alternatively, the option generally chosen in practice. Initially, the discussion for each component will follow Balas et al. (2009 [ms p. 10]) and consider only the black-letter law, i.e., the most "non-formalist" option allowed by the law. The numbers in the table at the end refer to this option. Then the discussion will also note, however, where usual practice does not follow the "non-formalist" approach. As will be

\footnotetext{
${ }^{2}$ The latter provision is made applicable in New York City by NYCRR 208.42(d). In England, CPR Part 55 II also offers an "accelerated possession claim", but this is confined to a limited class of possession claims not in principle based on unpaid rent (CPR Rule 55.11/12: undisputed claims brought under s. 21 Housing Act 1988 to recover possession under an assured shorthold tenancy), and hence the present discussion refers to the more general procedure. On the French "procédure de référé" (which is not limited to eviction or real estate litigation), see below n. 5 and accompanying text.

${ }^{3}$ Some of the variable definitions in Djankov et al. (2003) are phrased in terms of what is "normally" done, "most likely", etc. in the jurisdiction. This might suggest that prevailing practice should be decisive. However, the language of the variable definitions is not very precise in this regard. For example, the variable "filing" "equals one if the complaint is normally submitted in written form to the court, and zero if it can be presented orally." (Djankov et al. 2003,464 (emphasis added)). Both "alternatives” can obviously be true simultaneously.
} 
seen, the distinction is ultimately not crucial for assessing the relative "formalism" of the four jurisdictions. ${ }^{4}$

A particularly fundamental choice is that between the French standard procedure ("procédure au fond") and an accelerated and, in theory, preliminary procedure ("procédure en référé"). The discussion will generally refer to the latter, which is both less "formalist" and the standard choice of French landlords seeking an eviction. ${ }^{5}$ The problem is that the "procédure en référé" is not meant to handle seriously disputed cases, and would be converted into the standard "procédure au fond" if the judge had a serious doubt as to the right outcome of the case. Hence, if the judge thought that she needed to hear the witnesses nominated according to the World Bank instructions, the procedure would be converted. This would change the rules applicable to subsequent actions, which would matter notably for whether appeal suspends execution of the judgment. Since the World Bank instructions indicate, however, that the claimant is $100 \%$ right and the judge decides all motions for the claimant, it appears reasonable to assume that the judge will not consider it necessary to hear the proffered witness testimony and hence will not convert the procedure; this also corresponds to the reality of eviction proceedings where in the great majority of cases the respondents have no serious defense to offer (in fact, most do not even appear at trial, so that default judgment is entered against them).

\section{Ambiguous variable definitions in general}

Beyond parties' and judges' choices, ambiguous variable definitions are a more general problem. The discussion of the individual index components will reveal many more instances of it.

Given that the "formalism index" has 22 components, it is impractical to consider all possible permutations of different component interpretations, as done in Spamann (forthcoming) for the "antidirector rights index" (for example, with two possible interpretations per component, the number of permutations would be $2^{22}$ ). Fortunately, considering all permutations also appears unnecessary. The goal of the present exercise is to evaluate the formalism of civil procedure in the four key jurisdictions by the measure of the "formalism index", but otherwise independently of Djankov et al. (2003). This goal is well served by choosing in each case the most sensible interpretation, while indicating how different choices would influence the result.

As a byproduct, the discussion of component definitions' interpretation will demonstrate many occasions for misunderstanding that can wreak havoc on the consistency of data collected with the help of a large group of unconnected contributors.

\footnotetext{
${ }^{4}$ See below n. 51 and 53 and accompanying text.

${ }^{5}$ See JCl Proc. Civ. Fasc. 382 no. 26 et seq. (1995).
} 


\section{Legal Analysis}

\section{A. "Professionals vs. Laymen"6}

In all four jurisdictions, eviction proceedings are heard by a professional judge, but representation by a licensed attorney is not mandatory (in New York, legal representation would be required if the party were a corporation). ${ }^{7}$ In three jurisdictions, the competent court would be a specialized "small claims" court: the "Tribunal d'Instance" in France, the "Amtsgericht" in Germany, and the Housing Part of the New York City Civil Court in the US. ${ }^{8}$ In England, however, the "possession proceeding" must usually be litigated in the County Court, which is a court of general jurisdiction. ${ }^{9}$

\section{B. “Written vs. Oral”}

The complaint must be filed in writing in all jurisdictions except Germany. ${ }^{10}$ In Germany, submissions to the "Amtsgericht" may be made orally to the clerk of the court, even though litigants practically never avail themselves of this opportunity (indicating that the use of written documents can actually simplify things). ${ }^{11}$

${ }^{6}$ Quotations without attribution come from the subindex and component definitions in Table 1 in Djankov et al. (2003), which are reproduced in full in the table at the end of this Appendix.

${ }^{7}$ On the possibility to litigate without a lawyer, see Art. 827 NCPC (applicable also in "référé" procedures, see JCl Proc. Civ. Fasc. 382 no. 5 [1995]), § 78 ZPO, and for England Andrews para. 6.07-08. The New York exception is in CPLR § 321(a).

${ }^{8}$ See Art. L. 321-2-1 COJ (formerly Art. R. 321-2 COJ); § 23 no. 2(a) GVG; and CCA § 110(a)(5) and NYCRR 208.42(a). That being said, France and Germany have even "smaller" courts and procedures, respectively, that are not applicable in the eviction case: the "juge de proximité" in France, and the judge's discretionary choice of procedure in claims involving less than $€ 600$ in Germany (§ 495a ZPO).

${ }^{9}$ The County Court's jurisdiction in possession claims is laid down in CPR Rule 55.3(1); CPR Rule 55.3(3) with 55PD1.3 provides that a possession claim can be brought in the High Court's Chancery Division only in exceptional circumstances.

This Appendix follows Djankov et al. (2003) and classifies the County Courts as courts of general jurisdiction. In the final analysis, the reason is that they may hear nearly all types of claims, whereas the jurisdiction of the High Court is reserved for important or complex litigation with a value of $£ 15,000$ or more (cf. 07PD2.1 and 07PD2.4; and Zuckerman on Civil Procedure para. 3.7). The full argument, however, is much more complex than this. After all, like the competent courts in the other jurisdictions, the English County Court is the lowest available court, and it does have jurisdiction over small claims. The mere fact that, by its specific wording, the CPR frame the jurisdiction of the High Court as an exception to that of the County Court, rather than the other way around, could hardly be sufficient reason to consider the latter a "general" as opposed to "specialized jurisdiction court." Nor could the fact that the County Court handles the majority of all litigation (Andrews para. 22.02) - this is also true of the courts of the other jurisdictions listed above. Instead, what is determinative here is the considerably higher value threshold of County Court jurisdiction compared to these other courts. As already mentioned, this threshold is at least $£ 15,000$ (07PD2.1 and 07PD2.2), which is more than four times higher than that of the German "Amtsgericht" (€5,000, see §§ 71 I, 23 no. 1 GVG), and more than three times higher than for the French “Tribunal d'Instance” until 2003 (€7,600, see the former Art. R 321-1 COJ as amended by decree 2001-373 of 27 April 2001 with effect 1 January 2002; before that, the amount was FF50,000 since decree 98-1231 of 28 December 1998; the amount is now $€ 10,000$, see Art. L. 321-2, R. 311-1 COJ). In addition, the £15,000 threshold is only a lower limit, and other conditions need to be fulfilled for the case to go to the High Court, see 07PD2.4. These thresholds imply that the County Court will be much more geared towards sizeable claims than the other three courts.

${ }^{10}$ Cf. for England CPR Rules 7.2., 16.2, 55.3(5), 55.4, 22.1, PD55 1.5; for France Art. 53-55, 56 no. 1, 485, 651 para. 2 NCPC (the declaration to the clerk of the court, Art. 847-1 NCPC, is not applicable even in the "procédure au fond", since the expulsion claim is considered of indeterminate value, see Cass $\mathrm{Civ}^{2} 18$ 
Service of process is in writing in all four jurisdictions.

Only England requires that a defense be submitted in writing. ${ }^{12}$ France does not require a written defense, and oral defense is usual in practice, in part because of the fast pace of the "référé" procedure. ${ }^{13}$ German law does not require any answer before the hearing at the "Amtsgericht" unless the judge explicitly demands it from the defendant. ${ }^{14}$ Moreover, even if the judge so requires, the defendant may submit any defense orally to the clerk of the court, as with the complaint itself. ${ }^{15}$ If this were not sufficient for the "non-formalist" coding, New York would have to be classified as "formalist" as well: an answer is always required before the hearing of an eviction claim in the New York City Housing Part, but oral submission of the answer to the court clerk is possible. ${ }^{16}$

To classify the submission of "evidence" along the "written vs. oral" dimension, one needs to distinguish form and timing, as well as different types of evidence that require different answers. The index component definition refers to both form ("submitted to the court in written form") and timing ("presented at oral hearings before the judge").

- The question of form, however, is only relevant for witness evidence (by definition, documentary evidence is in written form). Witness evidence must always be given orally in open court in Germany and New York, and it may be so given at the choice of the parties and/or the judge in England and France. ${ }^{17}$ This also answers the question of timing. Hence all four jurisdictions are "non-formalist" for witness evidence.

- $\quad$ For documentary evidence, timing is the only relevant question. Only England requires its filing with the court before the hearing; the technicalities are left to a footnote. ${ }^{18}$ (In practice,

October 1978, Bull. Civ. II no. 209 and JCl Proc. Civ. Fasc. 210-2 no. 115 [1999]); for New York CCA § 902 and CPLR § 304.

${ }^{11} \S 496$ ZPO. This option is used in less than $1 \%$ of the cases brought in the Amtsgericht, see Klaus F. Rohl, Small Claims in Civil Court Proceedings in the Federal Republic of Germany, in SMALL Claims COURTS: A COMPARATIVE STUDY 167 (Christopher J. Whelan ed., Oxford 1990), at 173.

${ }^{12}$ For England, see CPR Rules 15.2, 15.4, 55.7(3)/(4). It is true that the only penalty for not filing a written defense is with respect to cost. Still, that should be sufficient legal motivation for a defendant to file the written defense.

${ }^{13}$ Cf. Art. 843 para. 1 NCPC (“La procédure est orale.”) and Serge Guinchard, MÉGA NouVEAu CODE DE PROCÉDURE CIVILE 834 n. 017 (Dalloz, $2^{\text {nd }}$ ed. 2001) (reporting the oral practice).

${ }^{14} \S \S 129$ para. 2, 495 ZPO, and see Thomas/Putzo-Reichold ${ }^{25} \S 495$ n. 3. It is true that German judges routinely make this demand (cf., e.g., Rohl, above n. 11). This is irrelevant for coding, however, in light of the possibility to submit the defense orally to the clerk discussed in the main text.

${ }^{15} \S 496 \mathrm{ZPO}$.

${ }^{16}$ See $\S 732(3)$ RPAPL (requirement for defendant to answer before trial), and § 743 RPAPL, 22 NYCRR 208.42(d) (example notice of petition) (possibility to submit answer orally to clerk of the court).

${ }^{17}$ For Germany, see $\S \S 355$ I, 375 ZPO (exceptions can be made for expert witnesses, see $\S \S 402,411$ ZPO). In New York, it seems there is no statutory provision explicitly addressing this (to New York lawyers) self-evident point, but see, e.g., the New York City Housing Part's instructions to litigants on its website: http://www.courts.state.ny.us/publications/L\&TPamphlet.pdf (visited 13 October 2006). In England and France, the parties and/or the judge also have the choice to introduce testimony in the form of affidavits, see for England CPR Rule 55.8(3)(b), and for France Art. 199 NCPC. For France, these sections refer to the full "au fond" procedure; as mentioned in Part A.2 above, an oral interrogation of witnesses should and does never happen in a "référé" procedure.

${ }^{18}$ In New York, the parties bring their documentary evidence with them to the trial, see the document cited in the previous note. By contrast, in England 55PD5.1 specifies that "[e]ach party should wherever possible include all the evidence he wishes to present in his statement of case" (i.e., the documents filed to 
witness statements predominate in easy English cases, and German litigants routinely attach copies of documents to their pleadings.)

In sum, dividing the coding equally between form and timing, and between witness and documentary evidence, France, Germany, and the US should be considered fully "non-formalist" and England $1 / 4$ "formalist" for "evidence".

Final arguments are given orally in all four jurisdictions.

The laws of all four jurisdictions also allow or even prefer that judgment be given orally directly at the close of the hearing. ${ }^{19}$ (Djankov et al. 2003 classify all four jurisdictions as rendering written judgments; this is probably a reflection of the prevailing practice. ${ }^{20}$ ) If this is so, "notification of judgment" will be oral as well (since this component seems to duplicate the previous one, one might want to omit it from the index; this is done for the count of practice below).

All jurisdictions rely on written documents for enforcement, which seems to be the only practicable solution.

\section{C. "Legal Justification"}

None of the four jurisdictions requires the complaint to contain references to "specific articles of the law or case-law", or other "legal reasoning" ${ }^{21}$ From this perspective, they should all be classified as "nonformalist" for the index component "complaint must be legally justified". There is an ambiguity in the component definition, however, that might warrant the opposite conclusion. Unlike the second sentence of the definition, the first sentence also mentions "formalities that would normally require legal training" as grounds for a "formalist" classification. Since all countries would be coded alike under either definition,

start the proceeding or in defense, cf. CPR Rule 2.3.(1)); cf. CPR Rule 55.8(4), which demands that "all witness statements must be filed and served at least 2 days before the hearing." For France and Germany, note first that the respondent's documentary evidence will automatically be filed in open court if an answer before the hearing is not required (see previous paragraph in the main text). For the rest, one needs to distinguish carefully between communication to the other party (i.e., a form of disclosure) and communication to the court. Only the former is required before trial, even though in practice the court will often receive the documents at the same time. In France, Art. 132 NCPC requires that the parties communicate documents they are relying on to each other without delay ("communication ... spontanée"), but this does not mean they have to give them to the court in advance of the hearing; Art. 56 para. 2 NCPC merely requires that the complaint contain a list of the documents that will be relied on. Similarly, in Germany § 131 I, III ZPO requires that copies of referenced documents be attached to the complaint or other pleading only if the other party does not yet have knowledge of them, which means in particular that it is not necessary to attach a copy of the lease agreement in an eviction proceeding.

\footnotetext{
${ }^{19}$ Art. 450 para. 1, § 310 para. 1 ZPO; CPLR § 4213(c); for England cf. Andrews para. 34.35-37.
}

${ }^{20}$ In spite of the codes' preference to the contrary, French judges virtually never give judgment directly at the end of the hearing, and German judges only rarely so (in about $10 \%$ of the cases); cf. Guinchard, Megacode NCPC, p. 458 no. 008 (France); Schellhammer ${ }^{10}$ I 728 (Germany). Steven Weller, John C. Ruhnka \& John A. Martin, American Small Claims Courts, in Whelan (ed.), above n. 11, 5, at 15-16, report the tendency of many judges to reserve judgment for US small claims courts generally; specific information on the New York City Housing Part's practice was unavailable.

${ }^{21}$ For France and Germany, this should be expected from the old civil law maxims "da mi factum, dabo tibi ius” and "curia novit ius”. Cf. for Germany § 253 para. 2 ZPO. In France since 1998, Art. 56 no. 2 NCPC requires that the complaint contain an exposition of the factual and legal arguments ("exposé des moyens en fait et en droit"). But this would be fulfilled in an eviction case by a simple reference to the tenant's default of payment. 
however, this distinction is ultimately without relevance for present purposes, and the details can be relegated to a footnote. ${ }^{22}$ The coding below treats all four jurisdictions as "non-formalist".

Nor do any of the four jurisdictions require that the judgment "expressly state the legal justification (articles of the law or case-law)." It is true that all three jurisdictions require some justification of the judgment, that the French and German statutes also require legal justification, and that as a matter of practice courts in all four jurisdictions will often explicitly mention statutes and (except in France) precedents. But neither jurisdiction requires specific references to statutes or precedents, as demanded by the component definition. ${ }^{23}$ Applying the component definition literally seems appropriate for two reasons. First, and generally, a literal reading of variable definitions commends itself to avoid confusion in the collection and verification of data, i.e., to enable replication by other researchers. Second, the literal reading also makes more sense in the present case: requiring explicit citations to statutory provisions and precedents does indeed seem "formalist", but a simple requirement to give reasons in - i.e., to explain! - a judgment seems more like a reflection of a fundamental right of the losing party (or, put differently, an important device for ensuring the population's continued acceptance of the legal system) ${ }^{24}$

The question whether "judgment must be on law (not on equity)" requires some interpretation because "equity" has a specific and legal meaning in the Common Law world, which cannot be translated into Civil Law terminology (even though the substantive solutions may be the same). Presumably, the definition refers to equity in a non-technical sense like "fairness". That still leaves the question how to classify broad standards within the fabric of legal rules, such as "good faith" or "reasonableness". Given that such standards are ubiquitous, however, it appears more appropriate to focus only on grants of complete judicial discretion, as in "amiable composition", "freies Ermessen”, or "just and equitable". None

${ }^{22}$ To start any legal proceeding in these four jurisdictions tends to be overwhelming for a layman-novice (even if experienced "laymen" may know the procedure and substantive law better than a lawyer who does not practice in the particular field). Cf. the advise on the New York Housing Part's website (http://www.courts.state.ny.us/courts/nyc/housing/represent.shtml, visited 27 August 2006): "If you are, or may be, a party in our court we strongly suggest that you consult an attorney to fully determine your legal rights and the best way of handling your legal problem." Similar instructions were issued in England, see Christopher J. Whelan, Small Claims in England and Wales, in Whelan (ed.), above n. 11, 99, at 124-28. In German Amtsgericht procedures generally (i.e., not limited to landlord and tenant disputes), lawyers were involved in $86.6 \%$ of the cases in 1984, see Rohl, above n. 11; this does not seem to have changed since.

England and New York require, for example, the use of a specific claim form for the complaint that must also be verified by a statement of truth, while France and Germany require certain content that may be common sense but that a layman might still not think about (such as the precise address of the defendant, or the name of the court). Cf. in England 55 PD 1.5, CPR Rules 22.1, 55.4; in France Art. 836, 56, 648 NCPC; in Germany §§ 130, 253 ZPO, 65 GKG; in New York RPAPL §§ 732(4), 741, and NYCRR 208.42(d). All jurisdictions have mechanisms other than attorneys to help laymen cope with those troubles: online forms and instructions in England, pro se clerks in New York, the sheriff ("huissier") in France, and the court clerk in Germany. The English forms are available online with instructions at www.hmcourtsservice.gov.uk (visited 27 August 2006). In France, the "huissier" who must be used for service of process would in fact draft the document to be served. For Germany, this is based on the assumption of oral filing of the complaint, as discussed above, in which case the court clerk would presumably see to it that the claimant add any missing information. For the provision of pro se clerks in New York, see CCA § 110(o); the necessary forms are also available at stationery shops.

${ }^{23}$ Cf. for England Andrews ch. 5.B; for France Art. 454, 455-1 NCPC ("Le jugement doit être motivé." the legal basis must be clear, but can be implicit, see JCl Civ. Proc. Fasc. 508 nos. 33-36); for Germany $\S$ 313 para. 1 no. 6, para. 3 ZPO (at least in simple cases, the need for legal justification does not mean that the judge needs to reference statutes and precedents explicitly, see Zöller ${ }^{25}$-Vollkommer $\S 313 \mathrm{n}$. 19; the divergent opinion of MüKo-ZPO ${ }^{2}$-Musielak $§ 313$ no. 15 seems unfounded); CPLR 4213(b) and NYCRR 208.43(i).

${ }^{24}$ See Weller, Ruhnka \& Martin, above n. 20, at 15. 
of the four jurisdiction grants the judge such powers in eviction proceedings. ${ }^{25}$ (Djankov et al. 2003 reach the same conclusion.)

\section{D. "Statutory Regulation of Evidence"}

Both England and France depart from the erstwhile "liberal democracy consensus" in civil procedure that the parties control the evidence, i.e., that the judge may not request by his own motion evidence not offered by the parties. ${ }^{26}$ The dividing line in this respect now runs between England and France on the one hand, and Germany and New York on the other, rather than between the Common and Civil Law countries.

Judges in all four jurisdictions can reject irrelevant evidence. ${ }^{27}$

The hearsay rule applies in the New York City Housing Part, so that "[o]ut-of-court statements are inadmissible" in New York; in England, the hearsay rule has been abolished; France and Germany never had it. ${ }^{28}$

All jurisdictions require a "written or magnetic record of all evidence introduced at trial"; England and New York even require that the hearing be recorded in its entirety, while a summary protocol suffices in France and Germany. ${ }^{29}$

Only France reserves the interrogation of witnesses and parties exclusively to the judge. ${ }^{30}$ One might wonder whether this includes, a fortiori, the requirement of the preceding index component that "the judge must pre-qualify the questions before they are asked to the witness." France would then qualify as "formalist" on both variables. Djankov et al. (2003), however, do not treat the latter variable in this way.

With respect to documentary evidence, the easy part is that all four jurisdictions allow uncertified copies in evidence. The hard part is to say whether in any of them "the authenticity and probative value of documentary evidence is specifically defined by the law", or whether "all admissible documentary evidence is freely weighted by the judge" (emphasis added). To answer that question precisely, one would have to know what type of documentary evidence is being used for what proposition. This is because all four jurisdictions know some rules of this type. ${ }^{31}$ For a simple eviction proceeding for failure to pay rent, it

${ }^{25}$ For New York, cf. PNY Realty Corp. v. Chong Leung Restaurant, 116 Misc.2d 1035, at 1038 (1982) (Housing Part has no general equity jurisdiction).

${ }^{26}$ See CPR Rule 32.1; Art. 10, 143 NCPC (limit: Art. 146 para. 2 NCPC). §§ 142, 143, 144, 273 II Nr. 2, 287 I 3, 448 ZPO grant some limited powers to the German judge to request or take certain evidence on her own initiative, but these are minor exceptions to the inverse rule.

${ }^{27}$ See Zöller ${ }^{22}$-Greger vor § 284 nos. 8b et seq. and Schellhammer ${ }^{10}$ qศ 538 -541 for Germany, and compare with, e.g., Michael M. Martin et al., New York Evidence Handbook ( $2^{\text {nd }}$ ed. 2003, Supp. 2004), § 4, in particular § 4.1 (one will find that the general statements in the German texts may sound more reserved, but the actual cases cited show that the rules operate in much the same way in both jurisdictions). For England, see CPR Rule 32.1; for France, see Art. 147 NCPC.

${ }^{28}$ Cf. for New York CCA § 110 (e) and 22 NYCRR 208.43(h) (providing that the rules of evidence apply in the Housing Part), and Michael M. Martin et al., previous note, §8 (explaining the hearsay rule in New York). By contrast, in England the hearsay rule has been abolished in civil proceedings by Section 1(1) Civil Evidence Act 1995, even though certain specificities remain (see Sections 2(1) and 4).

${ }^{29}$ See 39 PD 6; Art. 174, 182, 194, 219, 220, 282 NCPC; §§ 160, 510a ZPO; CCA § 110(k).

${ }^{30}$ See Art. 193, 214 NCPC. By contrast, see $\S 397$ II ZPO in Germany.

${ }^{31}$ E.g., the parol evidence rule in England and New York (in principle, written contract bars evidence of earlier or contemporaneous oral terms) (for England, see, e.g., Birk (ed.), English Private Law II, 8.82), or the French and German rule that the authentic signature proves that the undersigned made the declaration above (subject to counter-proof of fraud etc.), § 416 ZPO, Art. 1316-4 para. 1 CC (on this reading of Art. 1316-4 CC see JCl. Code Civil Art. 1316 - 1316-4, Fasc. 10 para 38 (2006); on the possibility of proving fraud etc., see, e.g., Stein/Jonas-Leipold § 416 nos. 12, 13 (1998)). 
is however hard to see how any of these rules would be relevant. Since moreover none of the four jurisdictions seems to be more "formalist" than others on this point, the solution adopted here is to classify all four jurisdictions as allowing free weighing of evidence, i.e., as "non-formalist."

\section{E. “Control of Superior Review”}

For intensity of appellate review, one might expect the Civil Law jurisdictions to be significantly stricter than the Common Law countries. ${ }^{32}$ However, all four jurisdictions allow appeal in this case ${ }^{33}$, and as the subindex components are defined, the strictest appellate review reigns in New York. This is because New York is the only jurisdiction where an appeal automatically stays execution. ${ }^{34}$ To be precise, this only applies if the defendant posts an undertaking not to commit waste and pay rent for the duration of the appeal, but the point is that this is entirely in the hands of the defendant - no judicial decision is necessary for the stay. (France's score for automatic stay would change if one assumed that the judge accepts the witness evidence and transforms the "référé" procedure into the standard "au fond" procedure. ${ }^{35}$ )

As to the scope of appeal, "issues of both law and fact (evidence) can be reviewed by the appellate court" (emphasis added) in all four jurisdictions. ${ }^{36}$ This includes England - the appellate court can review errors of fact as well as law. ${ }^{37}$

Finally, at least in principle all four jurisdictions allow interlocutory appeals - this should be a rarity in a simple eviction procedure, but they are not "always prohibited", as required by the component definition.

\section{F. "Engagement Formalities"}

With respect to the formalities involved in notifying the complaint and judgment, France stands out because it is the only one of the four jurisdictions to require that these documents be served by the sheriff

\footnotetext{
${ }^{32}$ Civil Law judiciaries are generally more hierarchical than Common Law judiciaries; in particular, they use appeals on a more systematic basis (Damaška 1986).

${ }^{33}$ See CPR Rule 52 and 53 PD 2A.1 (which court to appeal to depends on the court that decided at first instance); Art. L. 321-2-1 (formerly R. 321-2) COJ, 34, 543, 490 para. 1 NCPC (appeal to the "Tribunal de Grande Instance" - appeal is open because the expulsion claim is of indeterminate amount, see above n. 10; appeal is open regardless of whether the "procédure au fond" or the "référé" is used); § 511 para. 1, para. 2 no. 1 ZPO with § 72 GVG (appeal to the "Landgericht"); CCA § 1701 with 22 NYCRR 640.1 (appeal to the Appellate Term). Appeal is as of right in France, Germany, and the US; see the French and German provisions cited and CCA § 1702(a)(1). In England, appeal is open only with permission of the court, CPR 52.3.
}

Also, in England, s. 77(6) County Courts Act excludes appeal on any question of fact if, by virtue of the applicable statutory provision under which possession was granted, the Court can only grant possession on being satisfied that it is reasonable to do so. s. 77(6) gives a list of such statutory provisions. However, these referenced provisions do not include s. 7 Housing Act 1988, as it applies to the grounds in Part I of Schedule 2 to that Act (in particular ground 8: non-payment of rent).

${ }^{34}$ See CCA § 1703(a), CPLR 5516(a)(6) (this applies in tenant eviction proceedings, see, e.g., Wilber v. Abare 138 Misc.2d 754, at 762 (1988), and 3 Rasch’s Landlord and Tenant ${ }^{4} \S 47: 8$ ). For the lack of automatic stay in the other jurisdictions, see Art. 489 para. 1, 514 para. 2, 524 para. 2 NCPC, § 708 no. 7 ZPO, and CPR Rule 52.7. In Germany, the losing respondent is granted the possibility to avert execution pending appeal by posting a bond ( $\$ 711 \mathrm{ZPO}$ ), but, unlike in New York, the winning claimant can regain the right to execution by posting a bond himself (id.).

${ }^{35}$ See Art. 500-502, 504 NCPC and the discussion above in Part A.2.

${ }^{36}$ See CPR Rule 52.11(1)(b)/(4), Art. 561 NCPC, § 529 para. 1 ZPO, CPRL 5501(d).

${ }^{37}$ It may even choose to conduct a full rehearing, but this would be exceedingly rare in an eviction case. 
("huissier"). ${ }^{38}$ In England and Germany, this is done by the court simply through the postal service. ${ }^{39}$ In England, the party on whose behalf the document is served may also elect to arrange for service itself, as it would have to in New York. ${ }^{40}$

A conciliation attempt before filing the lawsuit is not required in any of the four jurisdictions. It is interesting to note, however, that all of them give the judge special powers and/or missions to facilitate settlement. ${ }^{41}$

\section{G. “Independent Procedural Actions"}

This last subindex is the predecessor to the complexity measure (number of steps) provided by later World Bank Doing Business reports and used in the present paper. It is omitted from the "formalism index" values provided below and in the paper to distinguish clearly between complexity and formalism. ${ }^{42}$ The discussion in this Section is provided for the sake of completeness only. It omits the last subindex component, the steps required for enforcement, because of considerable difficulties in counting those steps.

For the most part, the definition of the index component in Djankov et al. (2003) corresponds to that used by the World Bank. An "independent procedural action" is "a step of the procedure, mandated by law or court regulation, that demands interaction between the parties or between them and the judge or court officer" (emphasis added). Examples given include not only "filing a motion, attending a hearing, mailing a letter, or seizing some good", but also "every judicial or administrative writ or resolution". The one important difference between Djankov et al. (2003, 469) and the World Bank (2004, 42 and 109; and

\footnotetext{
${ }^{38}$ See in France Art. 54, 55, 485 para. 1, 651 para. 2 NCPC for service of process, and Art. 675 para. 1, 651 para. 2 NCPC for service of the judgment. Art. 61 of Law 91-650 of 9 July 1991 also requires formal service through the sheriff of a demand to surrender the premises ("commandement d'avoir à libérer les locaux") at least 2 months in advance of eviction; this can be combined with the service of judgment, Art. 194 decree 92-755.

${ }^{39}$ See CPR Rule 55.13(3) and §§ 271 I, 498, 166 II, 176 to 182 ZPO (these provisions came into force on 1 July 2002, but for the points relevant here the law was the same before). When effecting the service, the postal service, a private law company, is qualified by German law as a "beliehener Unternehmer", i.e., charged with specific public law duties and powers. But since it does not change the postal service's actual operation in delivering the process documents, this should not qualify the German postal service as a "judicial officer" for present purposes. One might view the incontournable intervention of the judge in the process in Germany as "service" through a judicial officer, but given that the judge does not serve herself and the arrangement of forwarding the documents directly to the other party actually saves the interested party time, this view is not adopted here (nor was it in Djankov et al. 2003).
}

${ }^{40}$ See in England CPR Rule 6.4(1), and in New York CRPL 304, RPAPL 731, 735, CCA 400, 403. Note that in any event the claim form (England) / notice of petition (New York) must be issued by the court before the claimant can commence service, cf. in England CPR Rule 7.2, and see in New York CCA 401(c) (which supersedes RPAPL 731(1)).

${ }^{41}$ See in England CPR Rules 26.4(2)(b)/(3) (court has power on its own initiative to order a stay of the proceedings to facilitate settlement); in France Art. 829 para. 1, 840, 841 NCPC (court will attempt settlement before proceeding to contentious hearing; query though whether these formally apply in the "référé" procedure") and, since 2003, Art. 829 para. 3 NCPC; in Germany § 278 ZPO (as in France); in New York NYCRR 208.03(b) and the Civil Court Directive re: Housing Court Initiative of 24 December 1997, as amended 5 October 2001, and available at http://www.courts.state.ny.us/courts/nyc/housing/directives/DRP/drp150.pdf\#search=\%22\%20\%22Resoluti on\%20Part\%22\%20site\%3Acourts.state.ny.us\%22 (case is sent to Resolution Part before being admitted, if no settlement is reached, to the Trial Part).

${ }^{42}$ As a practical matter, counting this subindex would be problematic because values need to be scaled relative to the sample minimum and maximum of the full 109-country sample, which, given the discussion of this section, might be quite different from those reported in Djankov et al. (2003) and, because of the different counting of contemporaneous actions, also from those reported in World Bank (2009). 
subsequent reports), however, is that only in the former, the "[a]ctions are always assumed to be simultaneous if possible, so procedural events that may be fulfilled in the same day and place are only counted as one action." This is crucial because it means that everything that happens at a hearing evidence-taking, arguments, judgment - counts as a single step. ${ }^{43}$

\section{Filing and Service}

For "filing and service" of process, the appropriate numbers appear to be 2, 4, 2-4, and 4 steps for England, France, Germany, and New York, respectively. ${ }^{44}$

\section{Trial and Judgment}

Since the trial can be held in one day in all jurisdictions and the judgment pronounced at the end of it, all four jurisdictions require only one step for the actual trial and judgment, at least if no witnesses are called (either because the parties do not suggest any or because the judge refuses their testimony as irrelevant). The number of additional steps required for opposition and/or notification of the trial date are (assuming as before that the parties and judges always make the "non-formalist" choice, and counting one party's communication of a document to both the court and the other party as two steps): 2 in England (filing of defense and service on claimant) ${ }^{45}, 0$ in France ${ }^{46}, 1$ in Germany (notification of hearing date to plaintiff) ${ }^{47}$, and 4 in New York (filing of answer and service on claimant, notification of hearing date to both parties). ${ }^{48}$

${ }^{43}$ Cf. the count of three steps for the "neighbor model” in Djankov et al. (2003,475): “(1) a claimant would request the judge's intervention, (2) the judge and the claimant would together meet the defendant and the judge would issue a decision following a discussion, and (3) the judgment would be enforced.”

${ }^{44}$ The respective sequences would be (counts in brackets):

England: claimant files the claim form and particulars of claim with the court (1), the court (or the claimant) serves the claim form and particulars on the respondent, usually by first class post (1) (cf. CPR Rule 6.2.(1)(b), 6.3, 7.2, 7.5(1), and in case of service by the claimant CPR Rule 55.8(6)). This assumes that the claimant files the claim form in person so that she can obtain a hearing date in that same step.

France: claimant charges the sheriff ("huissier") with service of the demand ("assignation") and files a notice to that effect or a copy with the court (2), the sheriff serves on the respondent and returns the process document to the claimant ( 2 - the claimant also needs to file the process document with the court, but usually does so only at the hearing so it is not counted as a separate step here) (cf. Art. 53-55, 56 no. 1, 485, 651 para. 2 NCPC, and Dalloz Action Proc. Civ. para. 1738 [on the necessity of delivering a copy of the process document, the practice of filing a notice or copy of the complaint with the court in advance of the hearing, and courts' practice not to admit the complaint to the hearing unless this has been done]).

Germany: plaintiff pays the court fee and files the complaint (whether this is 1 or 2 steps depends on whether the purchase of the necessary fee stamps in the courthouse counts as a separate step), court serves the complaint on the defendant through the postal service ( 1 or, if the postal service's return of the proof of service were to count as a step, 2) (cf. §§ 253 para. 5, 271 para. 1, 166 para. 2, 176 to 182 ZPO, 65 para. 1 phrase 1 GKG).

New York: claimant files petition and buys an index number from the clerk (1), claimant serves on respondent (1), claimant files with the court notice of petition with notarized affidavit of service (1), court addresses postcard to respondent (1) (cf. RPAPL § 732(1), NYCRR 208.42(d)/(i)).

${ }^{45} \mathrm{Cf}$. for this and the following CPR Rules 15.2, 15.4, 32.2(1)(b), 32.4, 32.6, 55.7, 55.8(1)/(3)/(4).

${ }^{46}$ Cf. Art. 10, 144, 148, 158, 432 para. 1, 841 NCPC.

${ }^{47}$ Cf. for this and the following $\S \S 495,497,129$ II, 270, 272, 273 I, II no. 4, III, IV 1, 274, 275 I and II, $310 \mathrm{I}$ and II ZPO.

${ }^{48}$ Cf. $\S 732(1) /(2)$ RPAPL. The hearing could count as two steps because of its bifurcation into proceedings before the Resolution and Trial Parts, see above n. 41 . 
The number of actions would increase in all jurisdictions except New York if one counted instead parties' and judges' usual choices, and/or let the witnesses be called to testify. While parties in New York proceedings must bring their witnesses to the first and only hearing, the other three jurisdictions would usually need to add another hearing if witnesses were to be called (1 additional step). ${ }^{49}$ More realistically though, English parties would introduce their witness testimony by way of witness statements, which need to be filed and served in advance of the hearing and would add 0 to 4 additional steps, depending on whether they are filed with the statement of case and the defense, respectively, or separately before the hearing. Witness statements might also be used in France (0 to 4 additional steps). In Germany, 2 steps need to be added in the realistic scenario where the court requires the respondent to file and serve a written answer; in that case, the court might be inclined to invite the witnesses to the first hearing, which would add another 2 steps because the parties would need to be informed of this.

In sum, "trial and judgment" would require from 3 to 7 steps in England, 1 to 6 in France, 2 to 6 in Germany, and 5 in New York. If one counted as only one step communication with the same content by one of the two parties to the court and the other party, or by the court to both parties ${ }^{50}$, the maximum numbers would be $4,2,4$, and 3 , respectively.

\section{Enforcement}

(Omitted)

\section{OVERall “Formalism IndeX” (NET OF “IndePEndent Procedural Actions”)}

The overall "Formalism Index" (net of "Independent Procedural Actions") is derived by adding the six subindices. According to the analysis of this Appendix, the values for England, France, Germany, and the US (New York) are 2.33, 2.76, 1.83, and 2.42, respectively. ${ }^{51}$ (By comparison, the corresponding numbers in Djankov et al. 2003 are 2.08, 3.54, 3.37, and 2.75.) By these numbers, Germany appears to be the least "formalist", far ahead of England, which in turn is only very slightly ahead of third-placed New York. While France is ranked lowest, the average rank of common and civil law systems is the same (2.5), and the average "Formalism Index" value for France and Germany is even lower than for England and the US.

The point of these numbers is not to argue that Germany is truly the least formalist of the four jurisdictions, or France the least. The "formalism index" is too coarse for such ranking exercises, even though it may be good enough for regression analyses. Rather, the point to make here is that actual index values may differ from those gathered in the first generation data collection, and that the picture with respect to legal origin may change as a result.

From a conceptual point of view, it is worth noting that France only does badly because it requires service of process and of the judgment by the "huissier" - without this requirement, France's index value would be 2.14, well lower than England's and New York's. Whatever one may think of the "huissier"'s mandatory intervention, it is hard to believe that it alone could be so important as to determine the relative worth of French civil procedure in a comparative perspective - or if it could, then the differences between these developed countries would be too small to be worth talking about. Similarly, Germany would fall back to third place if its postal service, when serving process or judgments, were qualified as a "judicial

\footnotetext{
${ }^{49}$ In France, this would require that the "référé" procedure be transformed into the standard "au fond" procedure.

${ }^{50}$ Whether this corresponds better to the variable definition depends on whether the place of written communication is where it is posted (two letters, one place $=1$ step) or where it is received (two letters, two places $=2$ steps).

${ }^{51}$ Counting judges' and parties' standard choices instead of black letter law, the corresponding numbers would have been 2.53, 2.96, 2.37, and 2.62, respectively (or 3.30 for France if one also assumed conversion of the "référé" procedure into the "au fond" procedure [which entails automatic suspension of enforcement pending appeal]). Hence, as mentioned above, the ordinal results of this Appendix are unaffected by this coding choice.
} 
officer", as German doctrine would have it. ${ }^{52}$ By contrast, changing the German law to the "formalist” rule on four key points such as whether evidence is received in writing, whether the weight of documentary evidence is defined by law, whether only the judge may ask questions to witnesses, and whether a written answer is required, would not have changed Germany's rank.

Another way to make the same point is to consider a different, and more straightforward, way of aggregating the individual components - simple unweighted summation of index components, instead of forming subindices resulting in different weights for individual index components. The sums of index components are 10 1/4, 11, 8, and 11 for England, France, Germany, and the US (New York), respectively. ${ }^{53}$ So with the most basic type of aggregation, the US would be as "formalist" as France, and England would be hardly any better.

\footnotetext{
${ }^{52}$ Cf. above n. 39.

${ }^{53}$ Counting judges' and parties' standard choices instead of black letter law, the corresponding numbers are $11,12,11 \frac{1 / 2}{2}$, and 12 , respectively, i.e., almost indistinguishable from each other.
} 
The table below reproduces the component definitions and values from Djankov et al. (2003) for the eviction of a residential tenant for failure to pay rent for Germany, France, England, and the US, and the values applied by the analysis of this Appendix. The numerical values from Djankov et al. (2003) are shown in the upper row, and those from this Appendix in the lower row. The numbers in bold represent subindex values, and the non-bold numbers below the individual components of that subindex. The subindex "independent procedural actions" is omitted, because improved data on a similar index (number of procedural steps) is now provided by the World Bank (2009) and treated separately in the paper (see above Part II.G). For references and explanations, see the discussion above.

\begin{tabular}{|lcccc|}
\hline & DE & FR & GB & US \\
\hline 1. PROFESSIONALS vS. LAYMEN: The index measures whether the resolution & .33 & .33 & .67 & .33 \\
of the case relies on the work of professional judges and attorneys, as opposed & .33 & .33 & .67 & .33
\end{tabular}

to other types of adjudicators and lay people....

(i) General jurisdiction court

The variable measures whether a court of general or of limited jurisdiction would be chosen or assigned to hear the case under normal circumstances. We define a court of general jurisdiction as a state institution, recognized by the law as part of the regular court system, generally competent to hear and decide regular civil or criminal cases. A limited jurisdiction court would hear and decide only some types of civil cases. Specialized debt-collection or housing courts, small-claims courts, and arbitrators or justices of the peace are examples. Equals one for a court of general jurisdiction, and zero for a court of limited jurisdiction.

(ii) Professional vs. non-professional judge

The variable measures whether the judge, or the members of the court or tribunal, could be considered as professional. A professional judge is one who has undergone a complete professional training as required by law, and whose primary activity is to act as judge or member of a court. A non-professional judge is an arbitrator, administrative officer, practicing attorney, merchant, or any other layperson who may be authorized to hear and decide the case. Equals one for a professional judge, and zero for a non-professional judge.

\section{(iii) Legal representation is mandatory}

The variable measures whether the law requires the intervention of a licensed attorney. The variable equals one when legal representation is mandatory, and zero when legal representation is not mandatory.

\section{WRITTEN VS. ORAL: The index measures the written or oral nature of the} actions involved in the procedure, from the filing of the complaint until the actual enforcement. ...

(i) Filing

Equals one if the complaint is normally submitted in written form to the court, 0 and zero if it can be presented orally.

\section{(ii) Service of process}

Equals one if the defendant's first official notice of the complaint is most likely received in writing, and zero otherwise.

(iii) Opposition

Equals one if under normal circumstances the defendant's answer to the complaint should be submitted in writing, and zero if it may be presented orally to court.

$\begin{array}{llll}0 & 0 & 1 & 0 \\ 0 & 0 & 1 & 0\end{array}$

$\begin{array}{llll}1 & 1 & 1 & 1 \\ 1 & 1 & 1 & 1\end{array}$

$\begin{array}{llll}0 & 0 & 0 & 0 \\ 0 & 0 & 0 & 0\end{array}$

$\begin{array}{llll}. \mathbf{8 8} & . \mathbf{7 5} & . \mathbf{7 5} & \mathbf{. 6 3} \\ .25 & .38 & .53 & .38 \\ & & & \\ 1 & 1 & 1 & 1 \\ 0 & 1 & 1 & 1 \\ & & & \\ 1 & 1 & 1 & 1 \\ 1 & 1 & 1 & 1 \\ & & & \\ 1 & 1 & 1 & 0 \\ 0 & 0 & 1 & 0\end{array}$




\begin{tabular}{|lllll|}
\hline & DE & FR & GB & US \\
\hline (iv) Evidence & 1 & 0 & 1 & 0 \\
Equals one if evidence is mostly submitted to the court in written form, in the & 0 & 0 & $1 / 4$ & 0 \\
form of attachments, affidavits, or otherwise, and zero if most of the evidence, \\
including documentary evidence, is presented at oral hearings before the judge.
\end{tabular}

(v) Final arguments 0

Equals one if final arguments on the case are normally submitted in writing, $\begin{array}{lllll}0 & 0 & 0 & 0\end{array}$

and zero if they are normally presented orally in court before the judge.

(vi) Judgment

Equals one if the judge issues the final decision in the case in written form, and zero if he issues it orally in an open court hearing attended by the parties. The defining factor is whether the judge normally decides the case at a hearing. If the judge simply reads out a previously made written decision, the variable equals one. Conversely, for an orally pronounced judgment that is later transposed into writing for enforcement purposes, the variable equals zero.

(vii) Notification of judgment

Equals one if normally the parties receive their first notice of the final decision in written form, by notice mailed to them, publication in a court board or gazette, or through any other written means. The variable equals zero if they receive their first notice in an open court hearing attended by them.

\section{(viii) Enforcement of judgment}

Equals one if the enforcement procedure is mostly carried out through the written court orders or written acts by the enforcement authority, and zero otherwise.
3. LEgAL JUSTIFICATION: The index measures the level of legal justification required in the process. ...

(i) Complaint must be legally justified

The variable measures whether the complaint is required, by law or court regulation, to include references to the applicable laws, legal reasoning, or formalities that would normally require legal training. Equals one for a legally justified complaint, and zero when the complaint does not require legal justification (specific articles of the law or case-law).

\section{(ii) Judgment must be legally justified}

The variable measures whether the judgment must expressly state the legal justification (articles of the law or case-law) for the decision. Equals one for a legally justified judgment, and zero otherwise.

(iii) Judgment must be on law (not on equity)

The variable measures whether the judgment may be motivated on general equity grounds, or if it must be founded on the law. Equals one when judgment must be on law only, and zero when judgment may be based on equity grounds.

\begin{tabular}{|c|c|c|c|c|}
\hline 4. STATUTORY REGULATION OF EVIDENCE: The index measures the level of & .5 & .13 & 0 & .13 \\
\hline $\begin{array}{l}\text { tatutory control or intervention of the administration, admissibility, evaluation } \\
\text { and recording of evidence. ... }\end{array}$ & 25 & 38 & .13 & .38 \\
\hline (i) Judge cannot introduce evidence & 1 & 0 & 0 & 1 \\
\hline Equals one if, by law, the judge cannot freely request or take evidence that has & 1 & 0 & 0 & 1 \\
\hline
\end{tabular}


not been requested, offered, or introduced by the parties, and zero otherwise.

(ii) Judge cannot reject irrelevant evidence

Equals one if, by law, the judge cannot refuse to collect or admit evidence requested by the parties, even if she deems it irrelevant to the case, and zero otherwise.

(iii) Out-of-court statements are inadmissible

Equals one if statements of fact that were not directly known or perceived by the witness, but only heard from a third person, may not be admitted as evidence. The variable equals zero otherwise.

\section{(iv) Mandatory pre-qualification of questions}

Equals one if, by law, the judge must pre-qualify the questions before they are asked of the witnesses, and zero otherwise.

(v) Oral interrogation only by judge

Equals one if parties and witnesses can only be orally interrogated by the judge, and zero if they can be orally interrogated by the judge and the opposing party.

(vi) Only original documents and certified copies are admissible Equals one if only original documents and "authentic" or "certified" copies are admissible documentary evidence, and zero if simple or uncertified copies are admissible evidence as well.

\section{(vii) Authenticity and weight of evidence defined by law}

Equals one if the authenticity and probative value of documentary evidence is specifically defined by the law, and zero if all admissible documentary evidence is freely weighted by the judge.

\section{(viii) Mandatory recording of evidence}

Equals 1 if, by law, there must be a written or magnetic record of all evidence introduced at trial, and 0 otherwise.

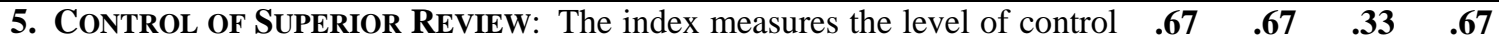 or intervention of the appellate court's review of the first-instance judgment. ...

$\begin{array}{llll}.67 & .67 & .67 & 1\end{array}$ \\ (i) Enforcement of judgment is automatically suspended until resolution of the appeal

$\begin{array}{llll}0 & 0 & 0 & 0\end{array}$

$\begin{array}{llll}0 & 0 & 0 & 1\end{array}$

Equals one if the enforcement of judgment is automatically suspended until resolution of the appeal when a request for appeal is granted. Equals zero if the suspension of the enforcement of judgment is not automatic, or if the judgment cannot be appealed at all.

(ii) Comprehensive review in appeal

Equals one if issues of both law and fact (evidence) can be reviewed by the appellate court. Equals zero if only new evidence or issues of law can be reviewed in appeal, or if judgment cannot be appealed.

\section{(iii) Interlocutory appeals are allowed}

Equals one if interlocutory appeals are allowed, and zero if they are always

prohibited. Interlocutory appeals are defined as appeals against interlocutory or interim judicial decisions made during the course of a judicial proceeding in first instance and before the final ruling on the entire case. 


\begin{tabular}{|c|c|c|c|c|}
\hline & DE & FR & GB & US \\
\hline 6. ENGAGEMENT FORMALITIES: The index measures the formalities required & $\mathbf{0}$ & .67 & $\mathbf{0}$ & $\mathbf{0}$ \\
\hline $\begin{array}{l}\text { to engage someone in the procedure or to hold him/her accountable of the } \\
\text { judgment. ... }\end{array}$ & $\mathbf{0}$ & .67 & $\mathbf{0}$ & $\mathbf{0}$ \\
\hline (i) Mandatory pre-trial conciliation & 0 & 0 & 0 & 0 \\
\hline $\begin{array}{l}\text { Equals one if the law requires plaintiff to attempt a pre-trial conciliation or } \\
\text { mediation before filing the lawsuit, and zero otherwise. }\end{array}$ & 0 & 0 & 0 & 0 \\
\hline (ii) Service of process by judicial officer required & 0 & 1 & 0 & 0 \\
\hline $\begin{array}{l}\text { Equals one if the law requires the complaint to be served to the defendant } \\
\text { through the intervention of a judicial officer, and zero if service of process may } \\
\text { be accomplished by other means. }\end{array}$ & 0 & 1 & 0 & 0 \\
\hline (iii) Notification of judgment by judicial officer required & 0 & 1 & 0 & 0 \\
\hline $\begin{array}{l}\text { Equals one if the law requires the judgment to be notified to the defendant } \\
\text { through the intervention of a judicial officer, and zero if notification of } \\
\text { judgment may be accomplished by other means. }\end{array}$ & 0 & 1 & 0 & 0 \\
\hline
\end{tabular}

\section{INDEPENDENT PROCEDURAL ACTIONS (not counted in overall index values} below): An independent procedural action is defined as a step of the procedure, mandated by law or court regulation, that demands interaction between the parties or between them and the judge or court officer (e.g., filing a motion, attending a hearing, mailing a letter, or seizing some goods). We also count as an independent procedural action every judicial or administrative writ or resolution (e.g., issuing judgment or entering a writ of execution) which is legally required to advance the proceedings until the enforcement of judgment. Actions are always assumed to be simultaneous if possible, so procedural events that may be fulfilled in the same day and place are only counted as one action. To form the index, we: (1) add the minimum number of independent procedural actions required to complete all the stages of the process (from filing of lawsuit to enforcement of judgment); and (2) normalize this number to fall between zero and one using the minimum and the maximum number of independent procedural actions among the countries in the sample. The index takes a value of zero for the country with the minimum number of independent procedural actions, and a value of one for the country with the maximum number of independent procedural actions.

\section{Filing and service}

The total minimum number of independent procedural actions required to complete filing, admission, attachment, and service.

\section{$\underline{\text { Trial and judgment }}$}

The total minimum number of independent procedural actions required to complete opposition to the complaint, hearing or trial, evidence, final arguments, and judgment.

\section{Enforcement}

The total minimum number of independent procedural actions required to complete notification and enforcement of judgment.

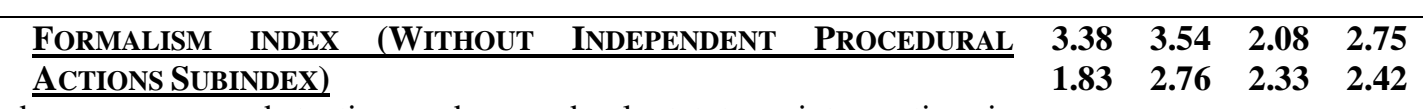

The index measures substantive and procedural statutory intervention in judicial cases at lower-level civil trial courts, and is formed by adding up the [6 


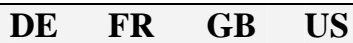

preceding sub-]indices ... 